Article

\title{
Enrichment of ATP binding proteins unveils proteomic alterations in human macrophage cell death, inflammatory response and protein synthesis after interaction with Candida albicans
}

Catarina Vaz, Jose Antonio Reales-Calderón, Aida Pitarch, María Luisa Hernáez, Perceval Vellosillo, Marco Trevisan-Herraz, Lucia Monteoliva, and Concha Gil

J. Proteome Res., Just Accepted Manuscript • DOI: 10.1021/acs.jproteome.9b00032 • Publication Date (Web): 15 Apr 2019

Downloaded from http://pubs.acs.org on April 22, 2019

\section{Just Accepted}

"Just Accepted" manuscripts have been peer-reviewed and accepted for publication. They are posted online prior to technical editing, formatting for publication and author proofing. The American Chemical Society provides "Just Accepted" as a service to the research community to expedite the dissemination of scientific material as soon as possible after acceptance. "Just Accepted" manuscripts appear in full in PDF format accompanied by an HTML abstract. "Just Accepted" manuscripts have been fully peer reviewed, but should not be considered the official version of record. They are citable by the Digital Object Identifier (DOI®). "Just Accepted" is an optional service offered to authors. Therefore, the "Just Accepted" Web site may not include all articles that will be published in the journal. After a manuscript is technically edited and formatted, it will be removed from the "Just Accepted" Web site and published as an ASAP article. Note that technical editing may introduce minor changes to the manuscript text and/or graphics which could affect content, and all legal disclaimers and ethical guidelines that apply to the journal pertain. ACS cannot be held responsible for errors or consequences arising from the use of information contained in these "Just Accepted" manuscripts. 


\section{Enrichment of ATP binding proteins unveils}

proteomic alterations in human macrophage cell

death, inflammatory response and protein

synthesis after interaction with Candida

albicans

Catarina Vaz $z^{\xi \notin}$, Jose Antonio Reales-Calderon ${ }^{\xi \&, \dagger}$, Aida $_{\text {Pitarch }}^{\xi \&,}$ Perceval Vellosillo $^{\S}$, Marco Trevisan ${ }^{\star}$, María Luisa Hernáez ${ }^{\ddagger}$, Lucía Monteoliva ${ }^{\S \& *}$ and Concha Gil $^{\& \& \neq}$

\section{AFFILIATION}

$\S$ Departamento de Microbiologia y Parasitología, Facultad de Farmacia, Universidad Complutense de Madrid, Madrid, Spain

\& Instituto Ramón y Cajal de Investigación Sanitaria IRYCIS, Madrid, Spain

キUnidad de Proteómica, Universidad Complutense de Madrid, Madrid, Spain

- Laboratorio de Proteómica Cardiovascular, Centro Nacional de Investigaciones Cardiovasculares Carlos III (CNIC), Madrid, Spain

Corresponding author e-mail: $\underline{\text { luciamon } @ \text { ucm.es }}$ 


\begin{abstract}
Macrophages are involved in the primary human response to Candida albicans. After pathogen recognition signaling pathways are activated, leading to the production of cytokines, chemokines and antimicrobial peptides. ATP binding proteins are crucial for this regulation. Here, a quantitative proteomic and phosphoproteomic approach was carried out for the study of human macrophage ATP-binding proteins after interaction with $C$. albicans. From a total of 547 non-redundant quantified proteins, 137 were ATP binding proteins and 59 were detected as differentially abundant. From the differentially abundant ATP-binding proteins, 6 were kinases (MAP2K2, SYK, STK3, MAP3K2, NDKA and SRPK1) most of them involved in signaling pathways. Furthermore, 85 phosphopeptides were quantified. Macrophage proteomic alterations including an increase of protein synthesis with a consistent decrease in proteolysis were observed. Besides, macrophages showed changes in proteins of endosomal trafficking together with mitochondrial proteins, including some involved in the response to oxidative stress. Regarding cell death mechanisms an increase of anti-apoptotic over proapoptotic signals was suggested. Furthermore, a high pro-inflammatory response was detected, together with no upregulation of key mi-RNAs involved in the negative feedback of this response. These findings illustrate a strategy to deepen the knowledge in the complex interactions between the host and the clinically important pathogen $C$. albicans.
\end{abstract}

Keywords: macrophages, Candida albicans, proteomics, SILAC, ATP binding proteins 


\section{INTRODUCTION}

Candida albicans is a human opportunistic pathogen and a common commensal fungus of the mucosa from many healthy patients. Most potentially lethal invasive infections occur in immunocompromised patients, such as those infected with HIV or individuals with neutropenia owing to immunosuppressive treatments for cancer or organ transplantation. ${ }^{1}$ Infections caused by Candida spp have high levels of morbidity and mortality particularly in critically ill patients that may be attributed to the difficulty in the early diagnosis of Candida infections and an appropriate antifungal therapy. ${ }^{2} \mathrm{~A}$ recent epidemiologic study in Spain described a 30\% of global mortality in the 705 documented cases of invasive candidiasis, and C. albicans was the most frequently isolated species, although an increase in non-C. albicans species has been observed. ${ }^{3} .2$ Macrophages, which are derived from monocytes circulating in the blood, are constantly patrolling tissues and non-sterile interfaces at the surfaces of epithelia, and are one of the key cells in the immune recognition and innate immune response to $C$. albicans. ${ }^{1}$ These cells recognize and phagocyte $C$. albicans, eliciting innate immune responses through engagement of different pattern recognition receptors (PRRs) in an infection-stage specific manner. ${ }^{4}$ Mainly, PRRs are composed of three groups: Toll-like receptors (TLRs), C-type lectin receptors (CLRs) and nod-like receptors (NODs). These PRRs, which include multiple cell-bound receptors (such as TLR2 and 4, Dectin-1 or Mannan Receptor), soluble receptors (like galectin-3), and intracellular receptors (like TLR 9), activate several signal transduction pathways, which finally lead to the upregulation of costimulatory molecules and the production of inflammatory cytokines, chemokines, antimicrobial peptides, and type I interferons (IFNs). ${ }^{5}$ Our research group identified new differentially abundant proteins in $C$. albicans-stimulated RAW 264.7 macrophages using proteomic approaches. ${ }^{6-7}$ 
Differentially abundant proteins were suggested to have pro-inflammatory and antiapoptotic effects. ${ }^{6-7}$ Another study on human M1 (classically activated, proinflammatory subtype) and M2 (alternatively activated, anti-inflammatory subtype) macrophages showed that the biggest differences between them were related to cytoskeletal rearrangement and metabolic routes ${ }^{8}$. Other studies analyzed the interaction between macrophage and Candida using proteomic approaches, and found proteins involved in energy metabolism, cell survival and candidates for interaction-specific molecules. ${ }^{9-10}$

Adenosine triphosphate (ATP) can bind to a group of proteins known as ATP-binding proteins. ATP-binding proteins were previously studied to elucidate molecular mechanisms in cancer, identify proteins that can be therapeutic targets for the development of novel antibiotics, and profile plant proteomes. ${ }^{11-14}$ However, their role is still poorly understood during different infection scenarios. This group of proteins include kinases, heat shock proteins as well as ATPases, and are crucial in several cellular processes, such as cell signaling, protein synthesis and metabolism. ${ }^{15}$ Despite the importance of these proteins in those pivotal cellular functions, proteomic studies of ATP-binding proteins by MS are still a challenge mainly due to the fact that some ATPbinding proteins are present at very low cellular concentrations. ${ }^{16}$ The combination of MS instrumentation with powerful separation techniques or selective enrichment of these proteins and bioinformatics tools can help in the identification and quantification of low abundant proteins in complex samples. ${ }^{11}$ Several procedures for selective enrichment of ATP binding proteins and kinases have been developed ${ }^{11,17-20}$, including a a probe-based technology that uses biotinylated acyl phosphates of ATP or adenosine diophosphate (ADP) that irreversibly react with protein kinases on conserved lysine residues in the ATP binding pocket. ${ }^{21}$ These probes covalently label the active site of 
ATPases, including chaperones and metabolic enzymes, to enable their selective enrichment using a desthiobiotin tag. The combination of metabolic labelling, such as stable isotope labeling by amino acids in cell culture (SILAC), with affinity enrichment was proven previously to be useful for quantification of subproteomes of interest. ${ }^{22-23}$ Moreover, protein post-translational modifications (PTMs) play a crucial role in the regulation of several biological processes, such as cell signalling, immune response, recognition of pathogens, among others. More than 300 types of protein PTMs are known to occur physiologically within living organisms. From these PTMs, the phosphorylation is highly important during signal transduction and it is believed that more than $30 \%$ of the proteins can be phosphorylated. ${ }^{24}$

A better understanding of the immune response during fungal infection may help in the development of new improved therapies in the future. We are particularly interested in unravelling new regulatory mechanisms activated by macrophages after interaction with C. albicans. Here, we study the abundances and phosphorylation levels of ATP-binding proteins in human macrophage cells after interacting with $C$. albicans. For that, SILAC was used to differentially label proteomes obtained from control macrophages and macrophages after interaction with C. albicans. The combined cell lysates were subjected to ATP-binding protein enrichment and a quantitative proteomic and phosphoproteomic approach was used to analyze the enriched extracts.

\section{MATERIALS AND METHODS}

\section{C. albicans strain}

The $C$. albicans SC5314 strain was used in this study. This strain was grown in YPD plates $(2 \%$ glucose, $1 \%$ yeast extract, $2 \%$ peptone and $2 \%$ agar $)$ at $30^{\circ} \mathrm{C}$. 


\section{THP-1 cell culture and macrophage differentiation}

The human acute monocytic leukemia cell line (THP-1) was cultured in Dulbecco's modified eagle's (DMEM) medium supplemented with antibiotics (penicillin 10000 U/ml-streptomycin 10000U/ml), 2 mM L-glutamine and 10\% heat-inactivated fetal bovine serum (FBS) at $37^{\circ} \mathrm{C}$ in a humidified atmosphere containing $5 \% \mathrm{CO}_{2}$. THP-1 cells were seeded in 24-well plastic plates at a density of $1 \times 10^{6}$ cells/well in complete medium and treated with a final concentration of $30 \mathrm{ng} / \mathrm{ml}$ phorbol 12-myristate 13 acetate (PMA; Sigma-Aldrich) for $48 \mathrm{~h}$ to induce maturation toward adherent macrophage-like cells. After $48 \mathrm{~h}$ cultures, the medium containing PMA was replaced with fresh medium without PMA to remove unattached cells.

\section{C. albicans-macrophage co-culture}

For interaction studies, THP-1 macrophages were incubated with C. albicans cells that were grown in YPD plates the day before, at multiplicity of infection (MOIs) of 1 and 5, and for different time points depending on the assays.

\section{Environmental scanning electron microscopy (ESEM)}

ESEM was performed as previously detailed. ${ }^{25}$ After macrophage interaction with $C$. albicans, cells were washed in PBS containing 2.5\% paraformaldehyde for $1 \mathrm{~h}$ at room temperature. They were incubated in $2 \%$ osmium tetroxide for $1 \mathrm{~h}$ and then in $2 \%$ tannic acid for $1 \mathrm{~h}$. Cells were dehydrated in ethanol. They were examined at the FEI INSPECT microscope at the Museo Nacional de Ciencias Naturales (Madrid, Spain).

\section{Cytokine determination}


For cytokines measurements, macrophages from the THP-1 cell line were incubated with or without $C$. albicans cells at an MOI of 1 for 3, 6 and $8 \mathrm{~h}$. As a positive control, macrophages were treated with lipopolysaccharide (LPS; 100ng/ml). Supernatants from untreated, LPS- or Candida-treated THP-1 macrophages were tested for cytokine production by ELISA using matched paired antibodies against different interleukins: IL$1 \beta$ IL6, IL-12p40 and TNF- $\alpha$ (Immunotools), according to manufacturer's instructions. Cytokine production was measured in three independent macrophage preparations.

\section{C. albicans phagocytosis assay}

C. albicans yeast cells were pre-labelled with $1 \mu \mathrm{M}$ Oregon green 488 (Molecular Probes) in the dark with gentle shaking at $30^{\circ} \mathrm{C}$ for $1 \mathrm{~h}$. THP-1 macrophages were differentiated in 18 -mm glass sterile coverslips placed into 24-well plates and confronted with the yeast cells at a $\mathrm{MOI}$ of 1 , at $37^{\circ} \mathrm{C}$ and $5 \% \mathrm{CO}_{2}$. Interaction was stopped after $45 \mathrm{~min}, 1.5 \mathrm{~h}$ and $3 \mathrm{~h}$, and cells were then washed with ice-cold PBS and fixed with $4 \%$ paraformaldehyde for $30 \mathrm{~min}$. To distinguish between internalized and attached/non-ingested yeasts, C. albicans cells were counterstained with $2.5 \mathrm{M}$ Calcofluor white (Sigma) for $15 \mathrm{~min}$ in the dark. After several washes, coverslips were mounted with specific mounting medium (Southern Biotech). The number of ingested cells (green fluorescence) and adhered/non-ingested (blue fluorescence) were calculated by fluorescence microscopy. ${ }^{26}$ Three different replicates with two different slides were prepared for each time point. At least 500 C. albicans cells were scored per slide, and results were expressed as the percentage of yeast cells internalized by macrophages.

\section{Macrophage cell damage assay}


In order to evaluate the $C$. albicans damage in the THP-1 cell line macrophages, the cytotoxicity detection kit (Roche) was used. This assay is based on the measurement of lactate dehydrogenase (LDH) activity released from the cytosol of damaged cells. Macrophages were cultured in 24-well plates as stated above, and C. albicans cells were incubated with them in a MOI of 1 and 5 at $37^{\circ} \mathrm{C}$ and $5 \% \mathrm{CO}_{2}$. The selected time points of measurements were 3 and $6 \mathrm{~h}$. After these time points, the supernatants of the cells were removed for LDH measurement. The assay was performed according to manufacturer's instructions.

\section{Macrophage cell line culture and SILAC labelling}

THP-1 monocytes were grown in DMEM containing 10\% dialyzed fetal bovine serum (FBS): i.e., either in light DMEM, containing $100 \mathrm{mg} / \mathrm{l}$ unlabeled L-arginine (Arg0) and 50 mg/l L-lysine (Lys0), or in heavy DMEM, containing 100 mg/1 Arg6 (Silantes, ${ }^{13} \mathrm{C}$ labelled Arginine $\cdot \mathrm{HCl}$ ) and $50 \mathrm{mg} / \mathrm{l}$ Lys6 (Silantes, ${ }^{13} \mathrm{C} 6$ labeled L-Lysine $\cdot \mathrm{HCl}$ ). After 5 cell doublings, protein lysates of the macrophage cells were analyzed by MS to ensure that all proteins were labelled. Differentiation of monocytes into macrophages was triggered by the addition of PMA. Approximately, 20x $10^{6}$ cells were plated in $150-\mathrm{mm}$ culture dishes and $30 \mathrm{ng} / \mathrm{ml}$ PMA was added, cells were incubated for two days to achieve complete differentiation. PMA was removed by washing the cells with light and heavy DMEM medium, respectively.

\section{Fungal infection for shotgun quantitative proteomics}

C. albicans cells were counted using the Neubauer chamber, and $20 \times 10^{6}$ cells were incubated with the macrophages (MOI of 1) for $3 \mathrm{~h}$. In order to diminish the possible effect of the labelling procedure, in two biological replicates control macrophages were 
labelled with light DMEM and macrophages upon interaction were labelled with heavy DMEM, while in the other two biological replicates this labelling was switched over. The extracted proteins came from the same number of macrophage cells in control and interaction conditions. In each experiment, both labelled and unlabeled lysates were mixed in protein concentration ratios of 1:1.

\section{Preparation of the protein samples for shotgun proteomics \\ Cell lysis}

After the incubation time, cells were washed twice with ice-cold PBS, and $1 \mathrm{ml}$ of cold modified radioimmunoprecipitation assay (RIPA) lysis buffer $(150 \mathrm{mM}$ sodium chloride; $50 \mathrm{mM}$ Tris- $\mathrm{HCl} \mathrm{pH}$ 7.5; 1\% NP40; 0.25\% sodium deoxycholate; proteases inhibitors (1:1000, Pierce $\left.{ }^{\mathrm{TM}}\right) ; 1 \mathrm{mM}$ sodium orthovanadate; $5 \mathrm{mM}$ sodium fluoride; 5 $\mathrm{mM} \beta$-glycerolphosphate and $5 \mathrm{mM}$ sodium pyrophosphate) was added. Cells were scrapped thoroughly. Then, the cell lysate was placed on ice for $5 \mathrm{~min}$, vortexed for another $5 \mathrm{~min}$, and centrifuged at 15,000 rpm for $10 \mathrm{~min}$ and $4^{\circ} \mathrm{C}$. The supernatant, containing the macrophage protein extract, was removed and transferred to a new tube. Protein concentration was measured using the Bradford assay.

\section{Kinase enrichment with ATP probes}

Protein lysates were enriched in kinases using ActivX desthiobiotin ATP probes (Thermo Scientific), according to manufacturer instructions with some alterations. Briefly, protein lysates were desalted using Zeba spin desalting columns to remove endogenous ATP. Then, lysates were eluted in reaction buffer and supplemented with protease inhibitors. Protein concentration was determined again by the Bradford assay. For labelling with the ATP probes, $2 \mathrm{mM} \mathrm{MgCl}$ was added to $2 \mathrm{mg}$ of protein lysate and 
incubated with $20 \mu \mathrm{M}$ of ActivX probe in a final volume of $500 \mu \mathrm{l}$ for $30 \mathrm{~min}$ at room temperature with constant mixing. Then, $500 \mu 1$ of $12 \mathrm{M}$ urea in lysis buffer were added to the lysate to stop the reaction. Samples were then incubated with $125 \mu$ of highcapacity streptavidin agarose resin for $1.5 \mathrm{~h}$ at room temperature with constant mixing. Beads were collected by centrifugation at $1000 \mathrm{~g}$ for 1 min and washed twice with $4 \mathrm{M}$ urea in lysis buffer. Finally, proteins were eluted by adding Laemmli reducing sample buffer and boiling for $5 \mathrm{~min}$.

\section{In-gel digestion}

Samples in Laemmli sample buffer were loaded into a $1.5 \mathrm{~mm}$ thick SDS-PAGE gel with a $4 \%$ stacking gel casted over a $10 \%$ resolving gel. The run was stopped as soon as the front entered $3 \mathrm{~mm}$ into the resolving gel so that the whole proteome became concentrated in the stacking/resolving gel interface. Bands were stained with colloidal Coomassie Brilliant Blue staining. Gels were cut into 12 to 15 slices for protein digestion. ${ }^{27}$ In-gel digestion was carried out as described. ${ }^{28}$ Briefly, gel slices were cut into pieces of $1 \mathrm{~mm}^{3}$ in size and washed with water. Proteins were reduced with $10 \mathrm{mM}$ DTT in $25 \mathrm{mM}$ ammonium bicarbonate for $30 \mathrm{~min}$ at $56^{\circ} \mathrm{C}$ and then alkylated with 55 $\mathrm{mM}$ iodoacetamide in $25 \mathrm{mM}$ ammonium bicarbonate for $15 \mathrm{~min}$ at $30^{\circ} \mathrm{C}$. Acetonitrile $(\mathrm{ACN})$ and vacuum centrifugation were applied to dry the gel pieces. They were then rehydrated with $60 \mathrm{ng} / \mu 1$ trypsin (proteomics grade; Roche Applied Science) in $25 \mathrm{mM}$ ammonium bicarbonate for $45 \mathrm{~min}$ at $4^{\circ} \mathrm{C}$. The trypsin solution was removed, and the rehydrated gel pieces were overlaid with $25 \mathrm{mM}$ ammonium bicarbonate. The digestion was performed overnight at $37^{\circ} \mathrm{C}$. After digestion, the supernatant was recovered. Peptides were extracted from the gel pieces with $30 \%$ ACN and $0.1 \%$ trifluoroacetic 
acid (TFA) for 30 min at room temperature. Peptides were desalted onto C18 OMIX cartridges and dried-down.

\section{Sequential elution from immobilized metal affinity chromatography (SIMAC) for phosphopeptide enrichment}

A total of $300 \mu \mathrm{g}$ of the protein lysate enriched in ATP-binding proteins was used for phosphopeptide enrichment. Both immobilized metal affinity chromatography (IMAC) and titanium dioxide $\left(\mathrm{TiO}_{2}\right)$ chromatography were performed as previously described ${ }^{7}$ and summarized below.

For each $100 \mu \mathrm{g}$ of peptides, $40 \mu \mathrm{l}$ of iron-coated PHOS-select ${ }^{\mathrm{TM}}$ metal chelate beads (Sigma-Aldrich) were used. Beads were washed twice in loading buffer $(0.1 \%$ TFA and $50 \% \mathrm{ACN}$ ), and incubated with $500 \mu \mathrm{g}$ of peptide mixture in loading buffer for $30 \mathrm{~min}$ at room temperature in vibrating shaker. Then, beads were packed in the constricted end of a $200 \mu$ GELoader tip by application of air pressure with a syringe, forming an IMAC column. The flow-through was collected for further analysis by $\mathrm{TiO}_{2}$ chromatography. The IMAC was then washed with loading buffer, which was added to the flow-through. Both monophosphorylated peptides and contaminating nonphosphorylated peptides were eluted using acidic elution solution (1\% TFA and 20\% $\mathrm{ACN}$ ) and the multiply phosphorylated peptides were eluted using basic elution solution ( $0.5 \%$ ammonia). The IMAC flow-through and both eluents were dried in a vacuum concentrator. $\mathrm{A} \mathrm{TiO}_{2}$ microcolumn was prepared by stamping out a small plug of $\mathrm{C} 18$ material from a C18 extraction disk and placing the plug in the constricted end of a 200 $\mu$ GELoader tip. The $\mathrm{TiO}_{2}$ beads were first suspended in loading buffer (1 M glycolic acid in 5\% TFA and 80\% ACN) and then mixed with the sample and incubated for 15 
min with constant mixing. This mixture was centrifuged and $90 \%$ of the supernatant was removed to minimize the volume introduced in the microcolumn. The sample was applied to the tip and the $\mathrm{TiO}_{2}$ column was packed by the application of air pressure with a syringe. The column was washed with loading buffer and subsequently with washing buffer ( $80 \%$ ACN and 5\% TFA). The phosphopeptides bound to the $\mathrm{TiO}_{2}$ microcolumn were eluted using $30 \mu \mathrm{l}$ of $0.5 \%$ ammonia followed by elution using $1 \mu \mathrm{l}$ of $30 \%$ ACN to elute phosphopeptides bound to the C18 disk. Then, the eluent was acidified by adding $5 \mu \mathrm{l}$ of $100 \%$ formic acid and dried in the vacuum concentrator.

\section{MS analysis}

Peptides were trapped onto a C18 SC001 2-cm precolumn (Thermo-Scientific), and then eluted onto a NS-AC-11 dp3 BioSphere C18 column ( $75 \mu \mathrm{m}$ inner diameter, $15 \mathrm{~cm}$ long, $3 \mu \mathrm{m}$ particle size; NanoSeparations) and separated using a 140 min gradient (0$40 \%$ buffer B for $120 \mathrm{~min}$; 40\%-95\% buffer B for $15 \mathrm{~min}$, and $95 \%$ buffer B for $5 \mathrm{~min}$; buffer $\mathrm{A}$ : $0.1 \%$ formic acid $/ 2 \% \mathrm{ACN}$; buffer $\mathrm{B}: 0.1 \%$ formic acid in $\mathrm{ACN}$ ) at a flow-rate of $250 \mathrm{~nL} / \mathrm{min}$ on a nanoEasy HPLC (Proxeon) coupled to a nanoelectrospay ion source (Proxeon). Mass spectra were acquired on a LTQ-Orbitrap Velos mass spectrometer (Thermo-Scientific) in the positive ion mode. Full-scan MS spectra $(\mathrm{m} / \mathrm{z} 300-1,900)$ were acquired in an Orbitrap at a resolution of 60,000 at $400 \mathrm{~m} / \mathrm{z}$ and the 15 most intense ions were selected for collision induced dissociation (CID) fragmentation in the linear ion trap with a normalized collision energy of 35\%. Singly charged ions and unassigned charge states were rejected. Dynamic exclusion was enabled with exclusion duration of $30 \mathrm{~s}$.

\section{Protein/peptide identification and quantification}


Mass spectra raw data files were searched against the SwissProt human database version 57.15 (20,266 protein entries) using MASCOT search engine (version 2.3, Matrix Science) through Proteome Discoverer (version 1.4.1.14; Thermo Fisher). Search parameters included a maximum of two missed cleavages allowed, carbamidomethylation of cysteines as a fixed modification, and oxidation of methionine, desthiobiotinylation of lysine, 13C-arginine and 13C-lysine as variable modifications. Precursor and fragment mass tolerance were set to $10 \mathrm{ppm}$ and $0.8 \mathrm{Da}$, respectively. Identified peptides were validated using Percolator algorithm with a qvalue threshold of 0.01 . Peptide quantification from SILAC labels was performed with Proteome Discoverer v1.4 using node precursor ion quantification. For each SILAC pair, the area of the extracted ion chromatogram was determined and the "heavy/light" ratio computed. Ratios were normalized by the median of all peptides ratios in each biological replicate. Media and standard deviation were calculated for each peptide. Protein ratios were then determined as the median of all the quantified peptides belonging to a certain protein. The quantification was analyzed at the peptide level, and peptide ratios were manually evaluated. Peptides that presented discrepant values inside each protein were discarded as soon as this elimination did not change the trend of the ratio presented, and the standard deviation was improved. By this way, an increase in the coverage of the quantified proteins was achieved.

Regarding phosphorylation, the variable modification of phosphorylation (STY) was added for peptide identification. The PhosphoRS node was used to provide a confidence measure for the localization of phosphorylation in the peptide sequences identified with this modification. The phosphorylation sites were manually corrected based on the PhosphoRS localization probability for a given residue. The phosphorylation sites assigned with a localization percentage $<75 \%$ were considered ambiguous. In addition, 
if the percentage was $>75 \%$ but different in the biological replicates were also considered ambiguous. The phosphopeptides were treated similarly as in quantitative analysis with the exception that the quantification was performed only at peptide level. Mass spectra raw data files (both quantitative and phosphorylation files) were also searched against the SwissProt human database for the discovery of possible missing proteins.

To make our findings publicly available and accessible to the community, we have deposited our dataset in ProteomeXchange Consortium via the PRIDE partner repository with the dataset identifier PXD009938.

\section{Western blotting}

Protein lysates were obtained as stated above but without cell labelling, and used for the proteomic validation assays. Forty $\mu \mathrm{g}$ of protein lysate were loaded in each well of a $10 \%$ SDS-PAGE gel and electrophoretically separated. After this, the proteins were transferred onto nitrocellulose membranes (Hybond-ECL; GE Healthcare). The membranes were blocked with 5\% skinny milk in PBS for $2 \mathrm{~h}$, and incubated with primary antibodies, including anti-PRDX5 (Abcam) (1/125), anti-MEK2 (Cell Signaling Technology) (1/500), anti-cleaved caspase-3 (Cell Signalling Technology) (1/1000), anti Erk-1/2 (Cell Signaling Technology) (1/1000), or anti-Tubulin- $\alpha$ (Serotec) (1/1000), anti P-Erk1/2 (Cell Signalling Technology) (1:1000) for $18 \mathrm{~h}$ at $4^{\circ} \mathrm{C}$. The membranes were washed 4 times with PBS containing $0.1 \%$ Tween-20 and incubated with IRDye ${ }^{\circledR}$ secondary antibodies for $1 \mathrm{~h}$ (1/4000 IRDye 800CW goat antimouse IgG, IRDye 680LT goat anti-mouse IgG, IRDye $800 \mathrm{CW}$ goat anti-rabbit IgG or IRDye 680LT goat anti-rabbit IgG, as appropriate). Membranes were then washed four times with PBS containing 0.1\% Tween-20. Odyssey system (LI-COR $®$ ) was used to 
detect the fluorescence signals. Protein abundance was compared between control and infected macrophages and values were given as arbitrary fluorescence units. Detection of tubulin- $\alpha$ was used as a loading control.

\section{Selected reaction monitoring (SRM)}

The abundance of the protein NDKA was quantified using SRM. A proteotypic peptide, which is a peptide unique to the target protein and easily detectable by mass spectrometry was selected for protein quantification. ${ }^{29}$ The selected peptide was FMQASEDLLK because it was quantified in the shotgun approach and reached several criteria necessary for SRM. These criteria were as follows: it should be proteotypic and easy to synthesize and have moderate hydrophobicity. Unpurified isotopic labelled peptide was obtained from JPT Peptide Technologies GmbH. Skyline software (Seattle Proteome Center) was used for the optimization of SRM methodology and for the analysis of the resulting MS data. Protein lysates were obtained as stated above, but without labelling the cells, enriched using ATP-probe and digested as previously shown. These SRM experiments were performed on a Q-TRAP ${ }^{\circledR} 5500$ LC-MS/MS system (AB Sciex). Both peaks from the endogenous and heavy peptides were evaluated manually. The area ratio (endogenous peptide area divided by heavy peptide area) was compared in both conditions (control and interaction). Three biological replicates and at least 2 technical replicates were performed.

\section{Bioinformatic analysis of the differentially abundant proteins}

Gene ontology (GO) enrichment analysis was performed using Genecodis (http://genecodis.cnb.csic.es/) $)^{30-32}$ and Panther (http://pantherdb.org/) web tools. For GO analysis, statistical significance was set at $p$-value $<0.05$. STRING software version 
10.0 (http://string-db.org) was used for the study of the protein-protein interactions. ${ }^{33}$ Ingenuity Pathway Analysis (IPA) (QIAGEN Bioinformatics) was used both for the prediction of possible upstream regulators and for network analysis.

\section{Quantitative RT-PCR}

RNA was isolated using the microRNeasy mini kit (QIAGEN) according to the manufacturer's protocol. Samples were quantified by Nanodrop 2000C (Thermo Fisher Scientific) and the presence of small RNA was confirmed using the Bioanalyzer 2100 (Agilent). Total RNA was reverse transcribed using Taqman microRNA reverse transcription kit (Thermo Fisher Scientific) and $10 \mathrm{ng}$ of total RNA from each sample. Quantitative real time polymerase chain reaction (RT-PCR) for miRNA was performed using TaqMan microRNA assays (Thermo Fisher Scientific) following the manufacturer's instructions. U6 snRNA was used as an endogenous control, and the microRNAs (miRNAs) analyzed were mmu-miR-124a, hsa-miR-146a, hsa-miR-155 and hsa-miR-21.

\section{Statistical analysis}

In the SILAC experiment, the protein abundance ratio was the amount of protein in the macrophages upon interaction with C. albicans divided by the amount of protein in the control macrophages (without interaction with C. albicans). The $\log _{2}$-transformed mean macrophage protein abundance ratios upon C. albicans interaction were stratified into seven quantiles according to their distribution in the sample: $\mathrm{Q}_{1}$ (the lower extreme values), $\mathrm{Q}_{2}$ (the lower outlier values), $\mathrm{Q}_{3}$ (the smaller values that extended to 1.5 times the lower quartile or $25^{\text {th }}$ percentile), $\mathrm{Q}_{4}$ (the interquartile range, i.e. $25^{\text {th }}$ to $75^{\text {th }}$ percentiles), $\mathrm{Q}_{5}$ (the larger values that extended to 1.5 times the upper quartile or $75^{\text {th }}$ 
percentile), $\mathrm{Q}_{6}$ (the upper outlier values), and $\mathrm{Q}_{7}$ (the upper extreme values). The first and seventh quantiles comprised those macrophage proteins that had the lowest and highest relative abundance ratios, respectively, upon interaction with C. albicans. The same analysis was performed for phosphorylated peptides. All quantitative data were presented as mean \pm standard deviation (SD).

For Western blotting, cytokines and SRM assays, comparisons between two groups were performed by the Student's t-test. Statistical significance was defined as * for $p$ value $<0.05, * *$ for $p$-value $<0.001$ and $* * *$ for $p$-value $<0.0001$. Three biological replicates were performed for Western blotting and SRM-based validation assays, with exception of cleaved-caspase Western blotting that was performed with two biological replicates.

The mi-RNA expression level was calculated using $\Delta \Delta \mathrm{Ct}$ formula. ${ }^{34}$ The results were represented using the relative fold-change expression compared to the control, where the control values were considered a value of 1 . Four biological replicates were used in this assay.

For all the assays, conditions were tested with Student's t-test. A $p$-value lower than 0.05 was considered statistically significant.

\section{RESULTS}

\section{THP-1 macrophages and $C$. albicans co-culture}

The optimal conditions were set up to characterize differentially abundant proteins from human macrophages upon C. albicans infection. The damage of C. albicans in the THP1 macrophages was evaluated by lactate dehydrogenase measurements in two MOIs (Figure 1A). C. albicans produced more damage to THP-1 cells in a MOI of 5 than in a MOI of 1 , as expected. Damage increased over time of incubation at both MOIs. A MOI 
of 1 was selected due to the lowest observed damage. After MOI selection, phagocytic activity was measured. C. albicans cells ingested or associated with macrophages were discriminated using differential staining with Oregon green and calcofluor white. THP-1 macrophages showed an increase in their phagocytic activity over time (from $45 \mathrm{~min}$ to $3 \mathrm{~h}$ ), almost $70 \%$ of Candida cells being engulfed after $3 \mathrm{~h}$ of interaction (Figures $1 \mathrm{~B}$ and C). Taking into account these results and some studies performed before by our laboratory, ${ }^{7-8,26,35}$ a MOI of 1 and the time point of $3 \mathrm{~h}$ were the conditions used for the quantitative proteomic assay. With these conditions, it was assured that $70 \%$ of C. albicans cells were engulfed and most macrophages were viable. Macrophage - $C$. albicans co-culture in the selected conditions was visualized by ESEM (Figure 1D). As shown, after $3 \mathrm{~h}$ of interaction C. albicans cells were already in hypha form and at different stages of interaction with the macrophage.

\section{Quantitative proteomic analysis of macrophage proteins after interaction with}

\section{C. albicans}

A quantitative shotgun proteomic approach using SILAC and LC-MS/MS was used to study the changes in the abundance of macrophage proteins enriched after using the ActivX desthiobiotin ATP probes upon interaction with C. albicans cells during $3 \mathrm{~h}$ at a MOI of 1. Protein lysate was enriched in ATP-binding proteins and samples were analyzed by LC-MS/MS. Four biological replicates and two technical replicates of each were analyzed by MS and a schematic workflow of the experimental procedure is reflected in Supplementary Figure 1. A total of 1043 proteins were identified, corresponding to $710,664,664$ and 709 proteins in each replicate, respectively (Supplementary Table 1 and Supplementary Figure 2). A total of 547 non-redundant proteins were quantified in at least two biological replicates with a $\mathrm{SD}<0.3$ 
(Supplementary Table 2). The molecular functions enriched on the 547 quantified proteins were mainly protein binding (271 proteins), nucleotide binding (203 proteins) and ATP binding (136 proteins). Furthermore, the total number of quantified proteins was enriched in 10 major biological processes, such as gene expression (87 proteins), cellular protein metabolic process (76 proteins), and translation (65 proteins). Regarding the cellular component, most of the proteins were located in cytoplasm (341 proteins), followed by nucleus (205 proteins), and mitochondria (105 proteins) (Supplementary Figure 3).

The macrophage proteins extracted using the ActivX desthiobiotin ATP probes showed a very homogeneous abundance ratio. After stratification of protein abundance ratios into quantiles according to their distribution upon interaction with C. albicans, we found that 4 and 9 proteins had the higher and lower extreme abundance ratios, whereas 18 and 28 proteins had the higher and lower outlier abundance ratios, respectively (Supplementary Figure 4 and Table 1). Out of these 59 differentially abundant proteins, 12 were annotated as ATP binding proteins. GO term enrichment analysis showed that the more abundant proteins were involved in gene expression and RNA metabolic process, whereas the less abundant proteins were associated with proteolysis, apoptotic processes and endocytosis, among others. Both, the more and less abundant macrophage proteins, were related to the same molecular functions, such as protein binding and nucleotide binding. Furthermore, the more abundant proteins were associated with RNA binding or peroxiredoxin activities, while the less abundant proteins were related to ATP binding or peptidase activities. Both the more and less abundant proteins were enriched in the cytosol and mitochondrion GO terms (Figure 2). The more abundant mitochondrial proteins during interaction included SLC25A24 and PRDX5, which are important in the response to oxidative stress ${ }^{36-37}$. 
The analysis of known and predicted protein-protein interactions was also performed with these 59 differentially abundant macrophage proteins upon C. albicans interaction (Figure 3). Forty-five protein-protein associations were found based on known or predicted interactions. Different clusters of protein associations were observed. A cluster enriched in proteins that were more abundant during $C$. albicans interaction was involved in protein synthesis. The group of proteins that were less abundant was very heterogeneous in molecular function GO terms and included a cluster of proteins involved in proteolysis and endocytic traffic. Other clusters containing both the more and less abundant proteins were related to RNA processing and apoptosis.

\section{Analysis of the quantified proteins annotated as ATP-binding proteins}

A comparison between all the proteins annotated as ATP binding in Uniprot database and the proteins quantified in this study was performed. From the 1482 proteins annotated with the ATP binding term, 137 were also present in the 547 proteins quantified in this study (Supplementary Table 2). This means that approximately $25 \%$ of all the quantified proteins were annotated as “ATP-binding”. A list of all ATP binding proteins quantified and grouped by protein family is represented in Table 2. Among them, 4 proteins (MAP2K2, KSYK, DDX21 and SYCC) were more abundant during the interaction, and 8 proteins (PRS10, SYIM, STK3, OAS3, MAP3K2, RTCB, NDKA and SRPK1) were less abundant after the interaction. In this group of differentially abundant ATP-binding proteins, 6 were kinases (MAP2K2, SYK, STK3, MAP3K2, NDKA and SRPK1). The group with more quantified proteins was the protein kinase superfamily, with 24 quantified protein kinases (Table 2). GO analysis on molecular function showed an over-representation of terms related to ATP binding (like nucleotide binding), ATPase activity and kinase activity (Supplementary Table 3). 
Regarding the GO analysis on cellular component, in addition to cytosol that was already expected, an over-representation on terms related to chaperonin-containing $\mathrm{T}$ complex, proteasome, mitochondria or extracellular vesicles was also observed. Concerning the GO analysis on the biological processes, there was an overrepresentation in terms such as regulation of protein localization to Cajal bodies (which are implicated in mRNA processing), ${ }^{38}$ tRNA aminoacylation for protein translation, protein folding, regulation of protein stability, and positive regulation of cellular biosynthetic process. There was also an over-representation on processes related to immune response, such as regulation of cellular response to stress and activation of innate immune response.

\section{Phosphoproteomic analysis of macrophage proteins after interaction with}

\section{C. albicans}

The fraction enriched in ATP-binding proteins from all 4 biological replicates was further subjected to phosphopeptide enrichment. A total of 85 phosphopeptides were quantified in at least two biological replicates and with a $\mathrm{SD}<0.3$ and are listed in Supplementary Table 4. In some cases two or more phosphopeptides were quantified for the same phosphorylation site (phosphosite). Therefore, 85 phosphopeptides corresponding to 70 phosphosites and 56 proteins were quantified. According to the phosphorylation probabilities given by the Proteome Discoverer software, the phosphosites were considered ambiguous or assigned to a specific amino acid (serine, threonine and tyrosine). Sixty-one percent of the phosphosites were phosphorylated in a serine and 33\% were ambiguous, whereas phosphothreonine and phosphotyrosine were less represented (3\% each). Out of the 56 phosphoproteins, 25 (approximately 36\%) are from proteins that were annotated as ATP-binding proteins in UNIPROT database and 
$12(21.4 \%)$ as kinases. Out of the 85 quantified phosphopeptides, 5 phosphopeptides (each one belonging to a single protein) were differentially abundant during macrophage interaction with C. albicans (Table 3 and Supplementary Figure 5). From this, 2 phosphopeptides belonging to PRKAA1 and CLN6 were more abundant during interaction, whereas 3 phosphopeptides belonging to PI4K2A, SRC and PRKCD were less abundant. Their mass spectra are shown in Supplementary Figure 6.

\section{Protein validation}

To confirm the quantitative MS data, Western blot analysis using antibodies to MAP2K2, PRDX5 and ERK1/2, and SRM of NDKA were performed. There was a significant increase in MAP2K2 (ratio between interaction and macrophages control of 1.6) and PRDX5 (ratio of 2.1) abundance during macrophage interaction with C. albicans cells in line with MS data (Figures 4A and 4B). Because MAP2K2 is a kinase that acts upstream ERK1/ERK2 kinases and is important for several cellular processes,${ }^{39}$ we also validated this protein by Western blotting. No significant differences in ERK1/2 abundance upon interaction were detected, confirming our proteomic data (Figure 4C). In addition, phosphorylation of ERK1/2 was also evaluated and no increase in phosphorylation was observed (Supplementary Figure 7). For SRM validation, the correspondent isotopic labelled peptide was ordered, and a calibration curve was performed (see Supplementary Figure 8and Supplementary Table 5). The quantification of this peptide confirmed the decrease in the amount of NDKA (ratio of 0.24) (Figure 4D and Supplementary Table 5).

\section{Macrophage cell death mechanisms and pro-inflammatory response}


Apoptosis was one of the biological processes enriched in the group of less abundant proteins. A closer look showed an increase in PRDX5, SLC25A24 and ADT2, which are anti-apoptotic proteins, and a decrease NDKA, ACTN4 and STK3, which are proapoptotic or anti-survival proteins ${ }^{36,40-44}$. In order to functionally validate these results, the apoptotic status of THP-1 macrophages after interaction with C. albicans was assayed by measuring caspase- 3 activation by cleavage. Cells were incubated with staurosporine (as a positive control of apoptosis) and with C. albicans cells (at a MOI of 1 for 3 h). Activated caspase- 3 was assayed by Western blotting with cell lysates and a band corresponding to the activated caspase 3 was observed in the positive control but not in macrophage-C. albicans interaction at $3 \mathrm{~h}$ (Figure 5A). As cleaved caspase 3 is a hallmark of apoptosis, ${ }^{45}$ this result suggests that apoptosis was not present in these conditions. In congruence with our results, it was previously described by others that C. albicans triggers pyroptosis during the first 6 to $8 \mathrm{~h}$ of interaction with macrophages, ${ }^{46}$ we checked IL- $1 \beta$ secretion (which is secreted after caspase-1 activation $)^{47}$. IL-1 $\beta$ was significantly more secreted in macrophages after interaction with C. albicans (Figure 5B). Furthermore, as pyroptosis is an inflammatory mechanism of cell death, ${ }^{47}$ other pro-inflammatory cytokines were evaluated. As depicted in Figures $5 \mathrm{C}$ and 5D, there was more secretion of pro-inflammatory cytokines IL-12p40 and TNF- $\alpha$ upon interaction with $C$. albicans.

To further predict potential upstream regulators implicated in the macrophage inflammatory response, the 59 differentially abundant proteins were also analyzed using the IPA software. Fifteen upstream regulators presented an activation $z$-score between 2 and 2 and a $p$-value of overlap $<0.05$, which included CD3 complex, cytokines (oncostatin M (OSM), IL5 and IL6), proteins (KRAS; VEGFA; MAPK1; ESR1), miRNAs (miR-124-3p and miR-21), transcription regulators (MYCN, MYC and TP53), 
transmembrane receptor CD28 and rapamycin-insensitive companion of mTOR (RICTOR) (Figure 6A). The higher or lower z-score showed the higher probability of activation or inhibition of the upstream regulator, respectively. The IL-6 gene was predicted to be inhibited. This prompted us to assay the secretion of this cytokine at different time points (3h, $6 \mathrm{~h}$ and $8 \mathrm{~h}$ ) of THP-1 macrophage-C. albicans interaction. This cytokine was not secreted after interaction with yeast cells (Figure 6B), indicating that this gene may not be expressed under these conditions. Due to the recent evidences in the implication of miRNAs ( $\mathrm{miR})$ in the regulation of innate immune response, ${ }^{48}$ we also evaluated the possible activation miR-21 and miR-124 (two miRNAs that were predicted to be activated; Figure 6A). The expression levels of miR-21 and miR-124 were evaluated together with miR-146 and miR-155 (which are activated after treatment with LPS in THP-1 cells ${ }^{24}$ and also after interaction with heat inactivated C. albicans cells $\left.{ }^{49-51}\right)$. MiR-21 and miR-124 were slightly, but not statistically significant, activated after treatment with LPS, and showed no significant activation in response to C. albicans (Figures 7A and 7B, respectively). Regarding miR-146 and miR-155, they were activated in response to LPS (Figures 7C and 7D, respectively), but also no significant activation in response to live $C$. albicans cells after $3 \mathrm{~h}$ and $6 \mathrm{~h}$ of interaction was observed.

\section{DISCUSSION}

The current approaches to decrease fungal infections are still limited and are mainly pathogen-directed therapeutics. ${ }^{52}$ In this way, the study of the immune response may give us new clues on how this pathogen can be killed, and consequently improve the currently available therapeutic approaches. Furthermore, increasing efforts are being done to develop specific ways to modulate the immune system as new therapeutic 
strategies. ${ }^{53-54}$ Macrophages are cells from the innate immune system that play an important role in the host response and elimination of pathogens. ${ }^{4}$ ATP-binding proteins are essential in several cellular processes including cell signaling, differentiation apoptosis and others. ${ }^{21}$ Despite this fact, proteomic studies of this group of proteins are generally difficult because they are at low abundance in the cell. In this way, we decided to perform a selective enrichment in ATP-binding proteins with an ATP probe ${ }^{16}$ in order to get more information on this subproteome. Taking advantage of this approach, a quantitative proteomic study of human macrophage proteins after interaction with C. albicans cells was carried out in this work and allowed the quantification of proteins that could be involved in the response to this pathogen. In this study, THP-1-derived macrophages were incubated with C. albicans cells during $3 \mathrm{~h}$ and a MOI of 1. PMA was used for the differentiation of THP-1 monocytes. The upregulation of specific genes during the differentiation process might overwhelm mild effects of specific stimuli. Nevertheless, this cell line was described to be very close to primary human cells and used previously for the study interaction with pathogens. ${ }^{55-59}$ At $3 \mathrm{~h}$ of interaction, a reduced damage was ensured, so $70 \%$ of the macrophages were not impaired and around $70 \%$ of yeast cells were engulfed by the macrophages. This evaluation of human macrophage interaction with C. albicans is in agreement with our previous studies with murine macrophage cell lines and was peremptory to select the ratio and time of incubation. ${ }^{7,26}$

\section{Enrichment in ATP binding macrophage proteins}

In this study, 547 non-redundant macrophage proteins were quantified, approximately $25 \%$ of which were annotated in Uniprot as "ATP-binding" proteins. Proteins that were quantified and not annotated as ATP binding proteins could be either proteins that were 
interacting with the ATP binding proteins or proteins that resulted from unspecific binding with the probe. The protein family with more quantified ATP-binding proteins was the protein kinase superfamily (with 24 quantified protein kinases). Out of these 24 protein kinases, 13 proteins were included in the Ser/Thr (STE) protein kinase family. The preference to this protein kinase family was previously observed by Lemeer and coworkers. ${ }^{60}$ They performed a comparison between two enrichment methods (ATPaffinity probe and kinobeads). They found a higher number of tyrosine kinases enriched with kinobeads, while more kinases from the STE kinase group were enriched with the ATP affinity probe. They detailed that small molecules inhibitors immobilized in kinobeads were originally developed to target tyrosine kinases, whereas the reaction mechanism of the ATP probe was distinct. ${ }^{60}$

\section{Differentially phosphorylated macrophage peptides after interaction with}

\section{C. albicans}

In addition to protein abundance, phosphorylation information can significantly enhance our knowledge on the involvement of macrophage ATP-binding proteins in different cellular mechanisms during interaction with pathogens. Furthermore, an important group of ATP binding proteins include kinases which are known to be highly phosphorylated in cell signaling processes where they are implicated. ${ }^{61}$ Although few phosphorylation results were obtained, 5 differentially abundant phosphopeptides were found and 4 of them were key kinases in cell signaling pathways. This means that type of enrichment in ATP binding proteins, coupled with the new and more potent mass spectrometers, can be a useful tool for the study of kinase phosphorylation sites. Regarding the more abundant phosphopeptides during macrophage-C. albicans interaction, they corresponded to CLN6 and PRKAA1. Neuronal ceroid lipofuscinosis 
are lysosomal storage disorders and mutation in CLN genes are the cause of this disease. Among them, CLN6 is involved in endocytosis of lysosomal proteins. ${ }^{62}$ However, little is known about this protein in other contexts. PRKAA1 presented the phosphopeptide that showed the highest increase in abundance during macrophage interaction. This protein is a sensor of energy status that maintains cellular energy homeostasis. ${ }^{63}$ The phosphorylation of Thr183 is known to activate this kinase. ${ }^{64-65}$ It was previously shown that the activation of this kinase was implicated in phagocytosis of both bacteria ${ }^{63}$ and fungi (like the pathogen Cryptococcus neoformans $)^{65}$. Phosphorylation of AMPK $\alpha$ in Ser487/491 was found to reduce AMPK activity ${ }^{66}$. In this study, the quantified AMPK $\alpha$ phosphopeptide had several possible phosphosites assigned: Ser494, Ser496 and Tyr500. A search in Phosphosite Plus ${ }^{\circledR}$ showed that the phosphorylation of Ser496 would be responsible for the inhibition of the enzymatic activity. However, further studies would be needed to know the cellular effects of this phosphopeptide.

The less abundant phosphopeptides during macrophage C. albicans interaction belonged to PRKCD, SRC and PI4K2. PRKCD and SRC are known to be activated after macrophage receptor recognition of C. albicans PAMPs. ${ }^{4,67}$ During this study, both phosphopeptides were found to be less abundant during interaction. SRC was found to be less phosphorylated in the activation site (Tyr419) during interaction. Due to its implication in several fundamental processes, including cell differentiation, proliferation, migration and survival ${ }^{68}$ in addition to its involvement in the inflammatory process, ${ }^{69}$ deeper analysis and time course experiment would be needed to further explain these results. In any case, SRC is one of the primary kinases to be activated after receptor engagement, ${ }^{4}$ it is plausible that after 3 hours of incubation this kinase is no longer phosphorylated, once the signaling cascades are already activated. 
PI4K2A was previously described to be involved in the correct endocytic traffic. ${ }^{70}$ Interestingly, the quantitative proteomic results showed that two proteins implicated in endosomal trafficking, RAB7A and TFR1, were less abundant during macrophage interaction with C. albicans..$^{71-73}$ These data together with the fact that our group previously supported the model where $C$. albicans evade trafficking to lytic compartments in murine macrophages ${ }^{35}$ make us hypothesize that also during this experiment C. albicans may be modulating phagosome maturation. This phenomenon was previously observed during macrophage-Mycobacterium tuberculosis interaction. ${ }^{71-}$ 72

\section{Mitochondrial proteins and oxidative stress response}

In general, the overall quantification of the ATP binding proteins subproteome enriched with this method presents slight changes in its abundance upon interaction with Candida. This may be due to the pre-activation with PMA needed to differentiate monocytes into macrophages. Macrophages are phagocytic cells that produce and release reactive oxygen species (ROS) in response to phagocytosis. ${ }^{74}$ Two mitochondrial proteins involved in response to oxidative stress (PRDX5 and SLC25A24) were found to be more abundant upon interaction with C. albicans. PRDX5, a protein that protects cells from DNA damage and inhibits stress-induced apoptosis, ${ }^{40}$ was previously shown to be more abundant in LPS-treated macrophages. ${ }^{75}$ We validated the increase in its abundance using Western blot. SLC25A24 may also play a role in protecting cells against oxidative stress-induced cell death. ${ }^{36}$ Another group previously observed significant changes in redox-related proteins implicated in oxidative burst in order to kill intracellular mycobacteria. They observed an increase in the abundance of several proteins that counteract the effect of oxidative stress. ${ }^{76} \mathrm{We}$ 
can hypothesize that the higher abundance of proteins that neutralize the oxidative burst may be a host-driving response to protect itself from the ROS production because after three hours of interaction Candida cells are already producing hypha which promotes phagolysosome rupture. Nevertheless, we may not discard the possibility that it can also be a pathogen-driven response (to reduce the production of ROS and decrease the killing power of the macrophages). In addition to being of highly importance to ATP production and electron transport chain, mitochondria were recently implicated in innate and adaptive immunity. ${ }^{77}$ Knowing this, we took a more careful look to the quantified proteins located in the mitochondria. In general terms, we observed an increase in the mechanisms that protect cell against oxidative stress as well as transport of ATP to the cytoplasm. This behavior is understandable once macrophages increase the amount of ROS to kill C. albicans. So, the increase in abundance of these proteins could play a role in the phagocyte protection against the produced oxidative stress. Furthermore, the higher demand of metabolites and proteins could explain the need of the mitochondria to increase the transport of ATP to the cytosol.

\section{Host proteins involved in mRNA processing and translation}

HNRNPCL1, a heterogeneous nuclear ribonucleoprotein, was the protein with the highest differential abundance in our study. HNRNPs are operationally defined as proteins that bind to $\mathrm{RNA}^{78}$ and are responsible for packing and stabilizing them. ${ }^{79}$ Little is known about HNRNPCL1. Nevertheless, HNRNPC was one of the first HNRNPs found to be involved in RNA splicing. ${ }^{80}$ The depletion of these $\mathrm{C}$ proteins from splicing extracts abolished splicing activity. Thus, we can hypothesize that HNRNPCL1, which has a 90.8\% identity with HNRNPC, may have a similar role to HNRNPC. Interestingly, an increase in the abundance of several HNRNPs was 
previously observed in THP-1 cells infected with Leishmania parasites. ${ }^{55}$ String analysis showed a cluster of (more and less abundant) proteins involved in RNA processing. Further validation and functional studies are necessary to define the role of splicing proteins in the macrophage response to C. albicans.

Another group of differentially more abundant proteins were ribosomal proteins (RPS26, RPL3, RPL9 and DDX21). A higher abundance of these proteins may be a mechanism of the host cells to meet the increasing need of proteins to fight the fungal infection. In line with the upregulation of the protein synthesis process, a decrease in the abundance of proteins involved in proteolysis (MMP9, LAP3, DPP7 and DLD) was observed.

\section{Macrophage cell death and inflammatory response to $C$. albicans}

We also observed enrichment of proteins related to apoptosis. We found that antiapoptotic signals were up-regulated in THP-1 macrophages infected with C. albicans, as compared to pro-apoptotic signals. Knowing that caspase-3 is one of the executioners of apoptosis, we measured its cleavage by Western blotting and no cleavage of this protein was observed after THP-1 macrophage interaction with C. albicans. ${ }^{81}$ A previous work from our research group reported no apoptosis in RAW 264.7 macrophages incubated with $C$. albicans. ${ }^{7}$ The way by which macrophages activate cell death mechanisms as a consequence of uptaking C. albicans cells has been studied previously. Uwamahoro and co-workers showed that $C$. albicans triggers pyroptosis during the first 6 to $8 \mathrm{~h}$ of interaction. ${ }^{46}$ In concordance to our results, they observed no evidence of activation of caspase-3 by C. albicans early post-infection. More recently, another group suggested that neutralization of the phagosome by $C$. albicans is an important signal in activating the macrophage inflammasome. ${ }^{82}$ The pro-inflammatory cytokine IL- $1 \beta$ is released as a 
result of C. albicans driven NL3PR inflammasome activation and has been used as a measurement of pyroptotic cell death in the immune cell in response to microbial pathogens. ${ }^{82-84} \mathrm{An}$ increase of this cytokine was observed after $3 \mathrm{~h}$ of interaction with C. albicans, suggesting that pyroptosis could be activated in response to C. albicans. However, further validation confirming caspase-1-dependent IL-1 $\beta$ release would be needed to confirm this phenomenon in this cell line. We were also interested in knowing whether other pro-inflammatory cytokines were secreted. Both TNF- $\alpha$ and Il-12 were significantly more secreted after $3 \mathrm{~h}$ of interaction with $C$. albicans. This pathogen is known to trigger a pro-inflammatory response of the macrophages, including the release of these cytokines. ${ }^{85}$ The IPA software was used to predict upstream regulators of the pro-inflammatory response. This analysis is based on prior knowledge of expected effects between transcriptional regulators and their target genes that are stored in Ingenuity ${ }^{\circledR}$ Knowledge Base (taking into account previously published datasets derived from different animal models). ${ }^{86}$ This analysis suggested 15 potential regulators of gene expression for the genes encoding the proteins identified in this. In order to validate some of these predictions, we evaluated the secretion of IL- 6 and the activation of miR21 and miR-124. The analysis performed by IPA presented a negative activation $z$-score of IL-6 and in accordance with this, no secretion of IL-6 was observed. IL-6 is a proinflammatory cytokine and was previously observed not to be secreted after interaction with C. albicans. ${ }^{8} 87$ Recently, mi-RNAs have been implicated in immune response, particularly as post-transcriptional regulators of the inflammatory response. There are several mi-RNAs that regulate TLR signaling pathways. Monk and co-workers showed that miR-155, miR-146a, miR-146b, miR-125a and miR-455 were upregulated after treatment with LPS and after interaction with heat killed C. albicans cells. ${ }^{51}$ Another group was interested in the impact of C. albicans cell morphology (heat killed yeast and 
hyphal cells) in the differential regulation of host mi-RNAs. ${ }^{50}$ They suggested that dectin-1 may be orchestrating miR-155 up-regulation in a Syk-dependent manner. Since our proteomic approach was performed with live $C$. albicans cells, we investigated the differential mi-RNAs regulation upon interaction with live Candida cells. The selected mi-RNAs were those predicted to be up-regulated by IPA (miR-21 and miR -124) and those found to be induced upon LPS activation and after interaction with heat killed $C$. albicans cells (miR-146 and miR-155). ${ }^{49}$ Because we used live cells, our time points were shorter than others. We found that miR-21 and miR-124 were slightly, but not significantly, up-regulated after treatment with LPS. After interaction with C. albicans, none of these mi-RNAs were statistically significant upregulated. In our conditions and time points, the results were different from the predicted by IPA. Both miR-146 and miR-155 were confirmed to be upregulated after macrophage treatment with LPS. This was in concordance with the other work where miR-146 was shown to be involved in the mechanism of negative feedback regulation of TLR. ${ }^{49}$ Interestingly, after macrophage interaction with live $C$. albicans cells, no upregulation of these mi-RNAs was observed at these time points. Although longer time points would be needed to determine whether this behavior is maintained, we can hypothesize that these miR were not yet activated because macrophages might need a much higher pro-inflammatory response to kill C. albicans, or because this fungus may be inducing a longer proinflammatory response to destroy the macrophage. The inflammatory effect induced by live C. albicans cells was previously suggested by our group as virulence trait responsible for tissue damage in the host. ${ }^{7,88}$ It is important to underscore the need of follow-up studies to reveal whether this is a host-driven or pathogen-driven mechanism. 


\section{CONCLUDING REMARKS}

The ATP-binding enrichment together with the SILAC proteomic and phosphoproteomic approach revealed new insights into the possible remodeling processes altered upon macrophage interaction with this human pathogen. A summary of these processes is depicted in Figure 8. Interestingly, an increase in the abundance of proteins involved in protein synthesis was observed together with an increase in the abundance of mitochondrial proteins responsible for macrophage response against oxidative stress. Regarding the cell death mechanisms, anti-apoptotic signals were more abundant than pro-apoptotic signals, in line with the lack of caspase-3 cleavage during interaction. A high pro-inflammatory response of the macrophage was observed, by the secretion of TNF- $\alpha$ and IL-12 cytokines together with the lack of activation of some miRNAs involved in the control of the pro-inflammatory response. Phosphorylation together with quantitative proteomic results suggested a possible reduction of the endosomal trafficking inside the macrophage. This study constitutes a valuable way to better understand cellular mechanism of response or readjustments and is important for the future development of new therapeutic approaches.

\section{FIGURE LEGENDS}

Figure 1. THP1 macrophage interaction with $C$. albicans cells. (A) Lactate dehydrogenase cytotoxicity assay to measure the damage of Candida cells in THP1 macrophages after $3 \mathrm{~h}$ and $8 \mathrm{~h}$ of interaction with C. albicans cells and at a MOI of 1 and 5. (B) Fluorescence microscopy images of THP1 macrophages exposed to labeled C. albicans strain SC5314 (Oregon green 488) in green, for 3h. Intracellular and external/adhered C. albicans cells were distinguished based on fluorescence after costaining with Calcofluor white in blue, which does not enter or stain macrophages. (C) 
Phagocytic activity of macrophages at different times of interaction. (D) Environmental scanning electronic microscopy (ESEM) of macrophage and C. albicans co-culture after $3 \mathrm{~h}$ of interaction

Figure 2. Gene Ontology (GO) analysis of the proteins considered differentially abundant after macrophage interaction with $\boldsymbol{C}$. albicans. GO analysis of (A) molecular function, (B) biological process and (C) cellular component.

Figure 3. Predicted protein-protein interacting network using STRING (v10.0). Some biological processes (RNA splicing, protein synthesis, proteolysis, endocytic traffic and apoptosis) are highlighted in the network, signaling some of the interacting proteins that are involved in each process. The network protein-protein interaction $p$ value was $5.76 \mathrm{e}^{-05}$.

Figure 4. Proteomic results validation in both conditions: $M \varphi$ (control) and M $\varphi+C$. albicans (MOI 1 and 3 h of incubation). Quantification of: (A) MAP2K2, (B) PRDX5 and (C) ERK1/2 by Western blotting and (D) NDKA by selected reaction monitoring.

Figure 5. Caspase 3 activation and cytokine secretion measurement. Caspase activation was measured by Western blotting (A) and cytokine secretion measured using Enzyme-Linked ImmunoSorbent Assay (ELISA): (B) Il-1 $\beta$, (C) IL-12p40 and (D) TNF$\alpha$ secretion in $\mathrm{M} \varphi$ (control) and $\mathrm{M} \varphi+C$. albicans and after treatment with LPS (positive control). 
Figure 6. Upstream-regulators predicted to be implicated in the response to C. albicans using Ingenuity ${ }^{\circledR}$ Pathway Analysis (IPA). The upstream regulators analysis is based on prior knowledge of expected effects between transcriptional regulators and their target genes stored in the IPA. (A) Bar chart of the upstream regulators that were predicted, including the activation z-score and p-value of each upstream regulator derived from IPA. Cellular validation of some of the upstream regulators was performed (B) IL-6 secretion by ELISA.

Figure 7. Expression levels of miRNAs in THP1 macrophages after interaction with C. albicans cells. Expression levels of (A) miR-21 and (B) mir-124 that were predicted by the IPA and (c) miR-146 and (D) miR-155 that were known to be activated after treatment with LPS and were used as controls.

Figure 8. Schematic overview of macrophage possible remodeling after interaction with C. albicans. The differentially abundant proteins, together with the cytokines, are color coded with red for more abundant and green for less abundant after macrophage interaction with $\mathrm{C}$. albicans. The cytokines and the miR that do not present differences after interaction are depicted in grey. The text describes some of the processes suggested to be remodeled after interaction.

\section{TABLES}

Table 1. List of proteins differentially abundant 3 hours after macrophageC. albicans interaction. Proteins are ordered by ratio average inside each category.

\begin{tabular}{|ccccccc|}
\hline $\begin{array}{c}\text { UniProt } \\
\text { Code }^{\mathrm{a}}\end{array}$ & $\begin{array}{c}\text { Entry } \\
\text { Names }\end{array}$ & $\begin{array}{c}\text { Gene } \\
\text { names }\end{array}$ & Protein Names $^{\mathrm{a}}$ & Ratio $^{\mathrm{b}}$ & $\begin{array}{c}\text { Standard } \\
\text { Deviation }^{\mathrm{b}}\end{array}$ & $\begin{array}{c}\mathrm{Nr} \\
\text { Replicates }^{\mathrm{c}}\end{array}$ \\
\hline
\end{tabular}


Proteins more abundant after macrophage interaction with $C$. albicans

RNA processing

Heterogeneous

060812 HNRC1 HNRNPCL1 nuclear $\begin{array}{lll}1.8 & 0.218 & 2\end{array}$ like 1

Small nuclear

$\begin{array}{lllllll}\text { P14678 } & \text { RSMB } & \text { SNRPB } & \begin{array}{c}\text { Small nuclear } \\ \text { ribonucleoprotein- } \\ \text { associated proteins }\end{array} & 1.5 & 0.045 & 3\end{array}$
$B$ and $B^{\prime}$

\begin{tabular}{|ccccccc|}
\hline Q99733 & NP1L4 & NAP1L4 & $\begin{array}{c}\text { Nucleosome } \\
\text { assembly protein 1- } \\
\text { like 4 }\end{array}$ & 1.4 & 0.169 & 2 \\
\hline Q01081 & U2AF1 & U2AF1 & $\begin{array}{c}\text { Splicing factor U2AF } \\
\text { 35 kDa subunit }\end{array}$ & 1.3 & 0.289 & 2 \\
\hline P09661 & RU2A & SNRPA1 & $\begin{array}{c}\text { U2 small nuclear } \\
\text { ribonucleoprotein A' }\end{array}$ & 1.2 & 0.205 & 2 \\
\hline Q9NR30 & DDX21 & DDX21 & $\begin{array}{c}\text { Nucleolar RNA } \\
\text { helicase 2 }\end{array}$ & 1.2 & 0.293 & 2
\end{tabular}

Structural components of ribosome

\begin{tabular}{ccccccc} 
P32969 & RL9 & RPL9 & $\begin{array}{c}\text { 60S ribosomal protein } \\
\text { L9 }\end{array}$ & 1.4 & 0.29 & 4 \\
\hline P62854 & RS26 & RPS26 & $\begin{array}{c}\text { 40S ribosomal protein } \\
\text { S26 }\end{array}$ & 1.3 & 0.166 & 2 \\
\hline P39023 & RL3 & RPL3 & $\begin{array}{c}\text { 60S ribosomal protein } \\
\text { L3 }\end{array}$ & 1.3 & 0.272 & 3
\end{tabular}

\section{Oxidative stress}

$\begin{array}{ccccccc}\text { P30044 } & \text { PRDX5 } & \text { PRDX5 } & \text { Peroxiredoxin-5 } & 1.3 & 0.171 & 2 \\ \text { Q6NUK1 } & \text { SCMC1 } & \text { SLC25A24 } & \begin{array}{c}\text { Calcium-binding } \\ \text { mitochondrial carrier } \\ \text { protein SCaMC-1 }\end{array} & 1.5 & 0.175 & 2\end{array}$

ATP production and transport

\begin{tabular}{ccccccc} 
O75964 & ATP5L & ATP5L & $\begin{array}{c}\text { ATP synthase subunit } \\
\text { g }\end{array}$ & 1.3 & 0.236 & 3 \\
\hline P05141 & ADT2 & SLC25A5 & ADP/ATP translocase & 1.2 & 0.227 & 4
\end{tabular}

Immune response and cell signalling

\begin{tabular}{|ccccccc|} 
P36507 & MP2K2 d & MAP2K2 & $\begin{array}{c}\text { Dual specificity } \\
\text { mitogen-activated } \\
\text { protein kinase kinase } \\
2\end{array}$ & 1.3 & 0.067 & 2 \\
\hline P43405 & KSYK & SYK & $\begin{array}{c}\text { Tyrosine-protein } \\
\text { kinase SYK }\end{array}$ & 1.2 & 0.187 & 2 \\
Q9NRN7 & ADPPT & AASDHPPT & $\begin{array}{l}\text { L-aminoadipate- } \\
\text { semialdehyde } \\
\text { dehydrogenase- } \\
\text { phosphopantetheinyl } \\
\text { transferase }\end{array}$ & 1.4 & 0.075 & 3 \\
\hline Q8NBX0 & SCPDL & SCCPDH & $\begin{array}{c}\text { Saccharopine } \\
\text { dehydrogenase-like } \\
\text { oxidoreductase }\end{array}$ & 1.3 & 0.066 & 2 \\
\hline Q9Y617 & SERC & PSAT1 & $\begin{array}{c}\text { Phosphoserine } \\
\text { aminotransferase }\end{array}$ & 1.3 & 0.275 & 2
\end{tabular}




\begin{tabular}{|c|c|c|c|c|c|c|}
\hline \multicolumn{7}{|l|}{ Others e } \\
\hline B2RPK0 & HGB1A & HMGB1P1 & $\begin{array}{l}\text { Putative high mobility } \\
\text { group protein B1-like } \\
1\end{array}$ & 1.3 & 0.251 & 3 \\
\hline P49589 & SYCC & CARS & Cysteine--tRNA ligase & 1.2 & 0.274 & 2 \\
\hline Q96QR8 & PURB & PURB & $\begin{array}{c}\text { Transcriptional } \\
\text { activator protein Pur- } \\
\text { beta }\end{array}$ & 1.2 & 0.285 & 4 \\
\hline Q9Y6C9 & $\mathrm{MTCH} 2$ & $\mathrm{MTCH} 2$ & $\begin{array}{l}\text { Mitochondrial carrier } \\
\text { homolog } 2\end{array}$ & 1.2 & 0.237 & 4 \\
\hline \multicolumn{7}{|c|}{ Proteins less abundant after macrophage interaction with $C$. albicans } \\
\hline \multicolumn{7}{|c|}{ Proteolysis and peptide degradation } \\
\hline Q9UHL4 & DPP2 & DPP7 & Dipeptidyl peptidase 2 & 0.8 & 0.213 & 3 \\
\hline P14780 & MMP9 & MMP9 & $\begin{array}{c}\text { Matrix } \\
\text { metalloproteinase-9 }\end{array}$ & 0.8 & 0.22 & 3 \\
\hline P28838 & AMPL & LAP3 & $\begin{array}{c}\text { Cytosol } \\
\text { aminopeptidase } \\
\end{array}$ & 0.8 & 0.237 & 4 \\
\hline Q96KP4 & CNDP2 & CNDP2 & $\begin{array}{c}\text { Cytosolic non-specific } \\
\text { dipeptidase }\end{array}$ & 0.8 & 0.076 & 2 \\
\hline P09960 & LKHA4 & LTA4H & $\begin{array}{c}\text { Leukotriene A-4 } \\
\text { hydrolase }\end{array}$ & 0.8 & 0.284 & 4 \\
\hline P09622 & DLDH & DLD & $\begin{array}{c}\text { Dihydrolipoyl } \\
\text { dehydrogenase }\end{array}$ & 0.8 & 0.163 & 2 \\
\hline \multicolumn{7}{|l|}{ Transport } \\
\hline Q8N5M9 & JAGN1 & JAGN1 & $\begin{array}{l}\text { Protein jagunal } \\
\text { homolog } 1\end{array}$ & 0.8 & 0.074 & 2 \\
\hline P51149 & RAB7A & RAB7A & $\begin{array}{c}\text { Ras-related protein } \\
\text { Rab-7a } \\
\end{array}$ & 0.8 & 0.223 & 2 \\
\hline P84085 & ARF5 & ARF5 & $\begin{array}{l}\text { ADP-ribosylation } \\
\text { factor } 5\end{array}$ & 0.8 & 0.162 & 3 \\
\hline \multicolumn{7}{|c|}{ Proteasome components and protein fate } \\
\hline P62333 & PRS10 & PSMC6 & $\begin{array}{l}26 \mathrm{~S} \text { protease } \\
\text { regulatory subunit } 10 \mathrm{~B}\end{array}$ & 0.9 & 0.104 & 3 \\
\hline P28065 & PSB9 & PSMB9 & $\begin{array}{c}\text { Proteasome subunit } \\
\text { beta type- } 9\end{array}$ & 0.8 & 0.276 & 2 \\
\hline O94874 & UFL1 & UFL1 & $\begin{array}{l}\text { E3 UFM1-protein } \\
\text { ligase } 1\end{array}$ & 0.8 & 0.281 & 3 \\
\hline P51572 & BAP31 & BCAP31 & $\begin{array}{c}\text { B-cell receptor- } \\
\text { associated protein } 31\end{array}$ & 0.8 & 0.127 & 2 \\
\hline \multicolumn{7}{|c|}{ Immune response and cell signalling } \\
\hline Q13188 & STK3 & STK3 & $\begin{array}{l}\text { Serine/threonine- } \\
\text { protein kinase } 3\end{array}$ & 0.8 & 0.061 & 2 \\
\hline Q9Y2U5 & M3K2 & MAP3K2 & $\begin{array}{c}\text { Mitogen-activated } \\
\text { protein kinase kinase } \\
\text { kinase } 2 \\
\end{array}$ & 0.8 & 0.2 & 3 \\
\hline P36873 & PP1G & PPP1CC & $\begin{array}{c}\text { Serine/threonine- } \\
\text { protein phosphatase } \\
\text { PP1-gamma catalytic } \\
\text { subunit } \\
\end{array}$ & 0.8 & 0.238 & 2 \\
\hline P09914 & IFIT1 & IFIT1 & $\begin{array}{c}\text { Interferon-induced } \\
\text { protein with } \\
\text { tetratricopeptide } \\
\text { repeats } 1 \\
\end{array}$ & 0.8 & 0.238 & 4 \\
\hline Q9Y6K5 & OAS3 & OAS3 & 2'-5'-oligoadenylate & 0.8 & 0.233 & 4 \\
\hline & & & & & & 37 \\
\hline
\end{tabular}




\begin{tabular}{|c|c|c|c|c|c|c|}
\hline \multicolumn{7}{|c|}{ synthase 3} \\
\hline \multicolumn{7}{|c|}{ Cytoskeleton components/interactors and regulators } \\
\hline Q15019 & SEPT2 & SEPT2 & Septin-2 & 0.8 & 0.003 & 2 \\
\hline P46940 & IQGA1 & IQGAP1 & $\begin{array}{c}\text { Ras GTPase- } \\
\text { activating-like protein } \\
\text { IQGAP1 }\end{array}$ & 0.8 & 0.168 & 3 \\
\hline P20700 & LMNB1 & LMNB1 & Lamin-B1 & 0.7 & 0.101 & 3 \\
\hline O43707 & ACTN4 & ACTN4 & Alpha-actinin-4 & 0.6 & 0.096 & 3 \\
\hline Q68CZ2 & TENS3 & TNS3 & Tensin-3 & 0.1 & 0.137 & 2 \\
\hline \multicolumn{7}{|c|}{ lon transport and uptake } \\
\hline Q13303 & KCAB2 & KCNAB2 & $\begin{array}{l}\text { Voltage-gated } \\
\text { potassium channel } \\
\text { subunit beta-2 }\end{array}$ & 0.8 & 0.093 & 2 \\
\hline P27105 & STOM & STOM & $\begin{array}{c}\text { Erythrocyte band } 7 \\
\text { integral membrane } \\
\text { protein }\end{array}$ & 0.8 & 0.253 & 4 \\
\hline P02786 & TFR1 & TFRC & $\begin{array}{l}\text { Transferrin receptor } \\
\text { protein } 1\end{array}$ & 0.5 & 0.115 & 2 \\
\hline \multicolumn{7}{|c|}{ RNA processing } \\
\hline Q9Y3I0 & RTCB & RTCB & $\begin{array}{l}\text { tRNA-splicing ligase } \\
\text { RtcB homolog }\end{array}$ & 0.8 & 0.087 & 2 \\
\hline P29692 & EF1D & EEF1D & $\begin{array}{c}\text { Elongation factor 1- } \\
\text { delta }\end{array}$ & 0.8 & 0.057 & 2 \\
\hline Q96SB4 & SRPK1 & SRPK1 & SRSF protein kinase 1 & 0.7 & 0.249 & 2 \\
\hline O43865 & $\mathrm{SAHH} 2$ & AHCYL1 & $\begin{array}{l}\text { Adenosylhomocystein } \\
\text { ase } 2\end{array}$ & 0.7 & 0.274 & 2 \\
\hline \multicolumn{7}{|c|}{ Nucleoside triphosphates synthesis } \\
\hline P15531 & NDKA d & NME1 & $\begin{array}{c}\text { Nucleoside } \\
\text { diphosphate kinase A }\end{array}$ & 0.8 & 0.228 & 2 \\
\hline P48047 & ATPO & ATP50 & $\begin{array}{l}\text { ATP synthase subunit } \\
\text { O }\end{array}$ & 0.7 & 0.098 & 3 \\
\hline \multicolumn{7}{|l|}{ Others ${ }^{e}$} \\
\hline Q9NSE4 & SYIM & IARS2 & $\begin{array}{l}\text { Isoleucine--tRNA } \\
\text { ligase }\end{array}$ & 0.9 & 0.14 & 3 \\
\hline Q96IJ6 & GMPPA & GMPPA & $\begin{array}{c}\text { Mannose-1-phosphate } \\
\text { guanyltransferase } \\
\text { alpha }\end{array}$ & 0.8 & 0.073 & 2 \\
\hline Q9NVJ2 & ARL8B & ARL8B & $\begin{array}{l}\text { ADP-ribosylation } \\
\text { factor-like protein } 8 \mathrm{~B}\end{array}$ & 0.8 & 0.215 & 3 \\
\hline Q6S8J3 & POTEE & POTEE & $\begin{array}{l}\text { POTE ankyrin domain } \\
\text { family member E }\end{array}$ & 0.6 & 0.089 & 2 \\
\hline Q01432 & AMPD3 & AMPD3 & AMP deaminase 3 & 0.5 & 0.278 & 4 \\
\hline \multicolumn{7}{|c|}{$\begin{array}{l}{ }^{b} \text { Average abundance ratio from macrophages }+C \text {. albicans versus control macrophages anc } \\
\text { respective inter-replicate standard deviation (cut-off in } 0.3 \text { ). }\end{array}$} \\
\hline \multicolumn{7}{|c|}{$\begin{array}{l}{ }^{c} \text { Proteins present in at least two biological replicates were considered and with a standard } \\
\text { deviation lower than } 30 \%\end{array}$} \\
\hline
\end{tabular}


e In this category were included proteins with unknown or putative function and proteins that were not possible to include in the others categories

Table 2. List of ATP-binding Proteins quantified. Proteins are ordered by alphabetical and by protein family.

\begin{tabular}{|c|c|c|c|c|}
\hline Protein Family & $\begin{array}{l}\text { UniProt } \\
\text { Code }^{\mathrm{a}}\end{array}$ & $\begin{array}{l}\text { Entry } \\
\text { name }\end{array}$ & $\begin{array}{l}\text { Gene } \\
\text { names }\end{array}$ & Protein Name \\
\hline \multirow{8}{*}{ AAA ATPase family } & P17980 & PRS6A & PSMC3 & $\begin{array}{c}26 \mathrm{~S} \text { protease regulatory subunit } \\
6 \mathrm{~A}\end{array}$ \\
\hline & P35998 & PRS7 & PSMC2 & $26 S$ protease regulatory subunit 7 \\
\hline & P43686 & PRS6B & PSMC4 & $\begin{array}{c}26 \mathrm{~S} \text { protease regulatory subunit } \\
6 \mathrm{~B}\end{array}$ \\
\hline & P46459 & NSF & NSF & Vesicle-fusing ATPase \\
\hline & P55072 & TERA & VCP & $\begin{array}{l}\text { Transitional endoplasmic } \\
\text { reticulum ATPase }\end{array}$ \\
\hline & P62191 & PRS4 & PSMC1 & $26 S$ protease regulatory subunit 4 \\
\hline & P62195 & PRS8 & PSMC5 & $26 S$ protease regulatory subunit 8 \\
\hline & P62333 & PRS10 & PSMC6 & $\begin{array}{c}26 \mathrm{~S} \text { protease regulatory subunit } \\
10 \mathrm{~B}^{\mathrm{b}}\end{array}$ \\
\hline \multirow{2}{*}{$\begin{array}{l}\text { ABC transporter } \\
\text { superfamily }\end{array}$} & Q03518 & TAP1 & TAP1 & Antigen peptide transporter 1 \\
\hline & P61221 & ABCE1 & ABCE1 & $\begin{array}{c}\text { ATP-binding cassette sub-family E } \\
\text { member } 1\end{array}$ \\
\hline \multirow{5}{*}{ Actin family } & P60709 & ACTB & ACTB & Actin. cytoplasmic 1 \\
\hline & P68032 & ACTC & ACTC1 & Actin. alpha cardiac muscle 1 \\
\hline & P61163 & ACTZ & ACTR1A & Alpha-centractin \\
\hline & P61160 & ARP2 & ACTR2 & Actin-related protein 2 \\
\hline & P61158 & ARP3 & ACTR3 & Actin-related protein 3 \\
\hline \multirow{2}{*}{$\begin{array}{l}\text { Adenylate kinase } \\
\text { family }\end{array}$} & P00568 & KAD1 & AK1 & Adenylate kinase isoenzyme 1 \\
\hline & P30085 & $\mathrm{KCY}$ & CMPK1 & UMP-CMP kinase \\
\hline \multirow{3}{*}{$\begin{array}{l}\text { ATPase alpha/beta } \\
\text { chains family }\end{array}$} & P06576 & ATPB & ATP5F1B & ATP synthase subunit beta \\
\hline & P25705 & ATPA & ATP5F1A & ATP synthase subunit alpha \\
\hline & P38606 & VATA & ATP6V1A & $\begin{array}{c}\text { V-type proton ATPase catalytic } \\
\text { subunit A }\end{array}$ \\
\hline \multirow{7}{*}{$\begin{array}{l}\text { Class-I aminoacyl- } \\
\text { tRNA synthetase } \\
\text { family }\end{array}$} & P23381 & SYWC & WARS & Tryptophan-tRNA ligase \\
\hline & P26640 & SYVC & VARS & Valine-tRNA ligase \\
\hline & P47897 & SYQ & QARS & Glutamine-tRNA ligase \\
\hline & P49589 & SYCC & CARS & Cysteine-tRNA ligase $^{c}$ \\
\hline & P54136 & SYRC & RARS & Arginine-tRNA ligase \\
\hline & P54577 & SYYC & YARS & Tyrosine-tRNA ligase \\
\hline & Q9NSE4 & SYIM & IARS2 & Isoleucine-tRNA ligase ${ }^{b}$ \\
\hline
\end{tabular}




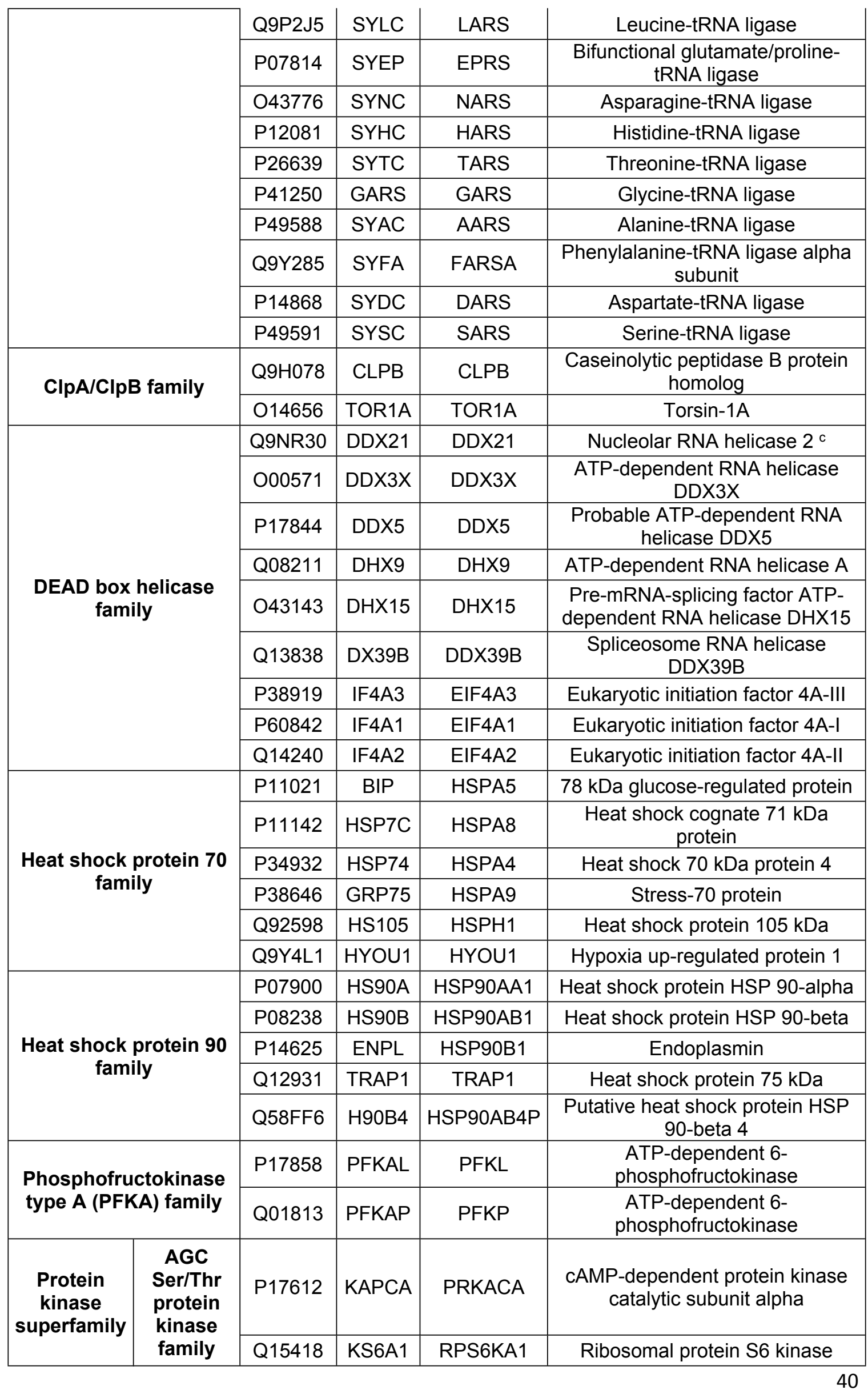




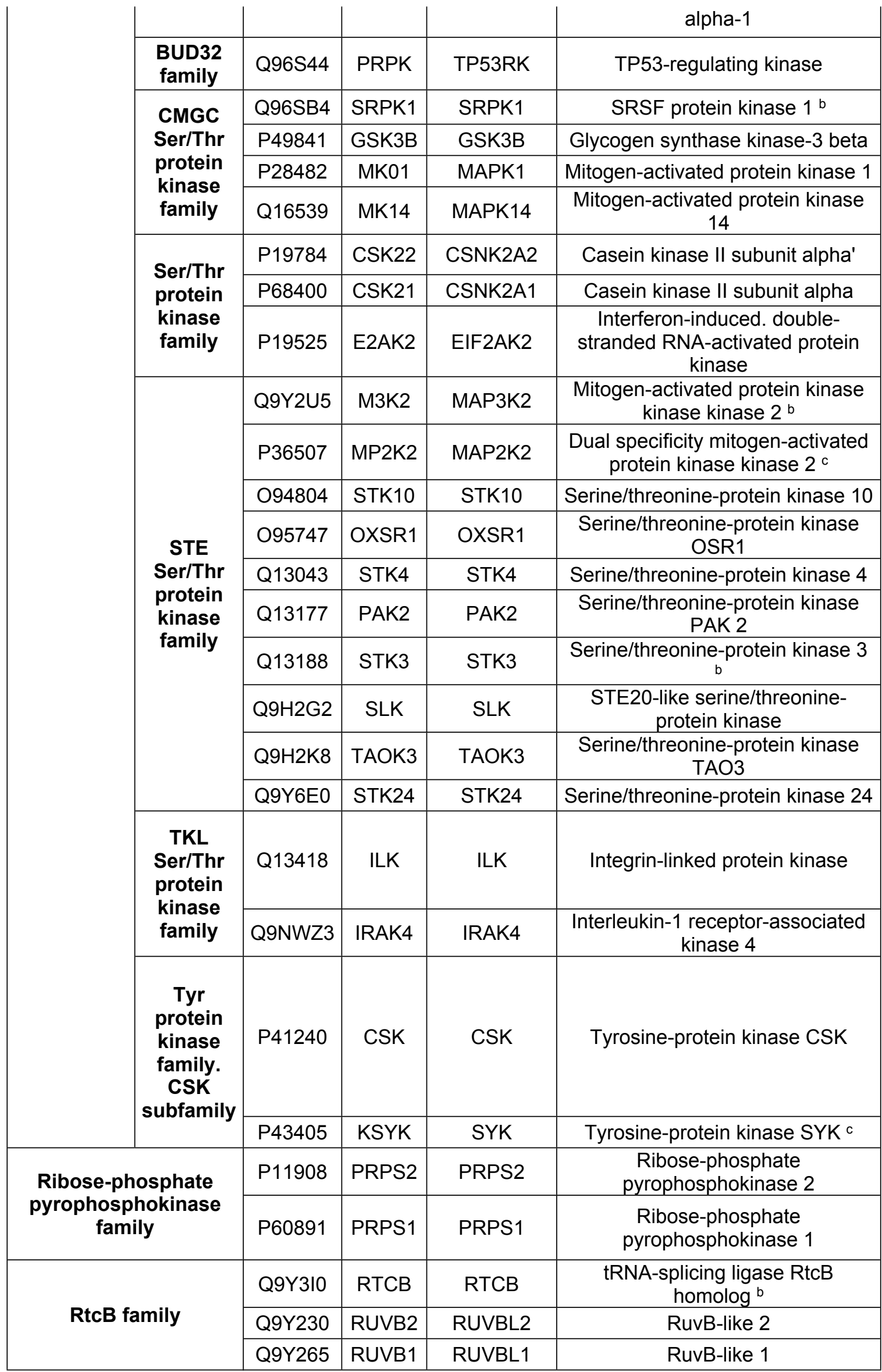




\begin{tabular}{|c|c|c|c|c|}
\hline \multirow{3}{*}{$\begin{array}{l}\text { Succinate/malate CoA } \\
\text { ligase beta subunit } \\
\text { family }\end{array}$} & Q9P2R7 & SUCB1 & SUCLA2 & Succinate-CoA ligase \\
\hline & Q96199 & SUCB2 & SUCLG2 & Succinate-CoA ligase \\
\hline & P53396 & ACLY & ACLY & ATP-citrate synthase \\
\hline \multirow{8}{*}{$\begin{array}{l}\text { TCP-1 chaperonin } \\
\text { family }\end{array}$} & P17987 & TCPA & TCP1 & T-complex protein 1 subunit alpha \\
\hline & P40227 & TCPZ & CСT6А & T-complex protein 1 subunit zeta \\
\hline & P48643 & TCPE & CCT5 & $\begin{array}{l}\text { T-complex protein } 1 \text { subunit } \\
\text { epsilon }\end{array}$ \\
\hline & P49368 & TCPG & ССТ3 & $\begin{array}{c}\text { T-complex protein } 1 \text { subunit } \\
\text { gamma }\end{array}$ \\
\hline & P50990 & TCPQ & ССТ8 & T-complex protein 1 subunit theta \\
\hline & P50991 & TCPD & CCT4 & T-complex protein 1 subunit delta \\
\hline & P78371 & TCPB & ССТ2 & T-complex protein 1 subunit beta \\
\hline & Q99832 & $\mathrm{TCPH}$ & ССT7 & T-complex protein 1 subunit eta \\
\hline \multirow{5}{*}{$\begin{array}{l}\text { Ubiquitin-activating E1 } \\
\text { family }\end{array}$} & A0AVT1 & UBA6 & UBA6 & $\begin{array}{l}\text { Ubiquitin-like modifier-activating } \\
\text { enzyme } 6\end{array}$ \\
\hline & P22314 & UBA1 & UBA1 & $\begin{array}{c}\text { Ubiquitin-like modifier-activating } \\
\text { enzyme } 1\end{array}$ \\
\hline & Q9UBT2 & SAE2 & UBA2 & $\begin{array}{l}\text { SUMO-activating enzyme subunit } \\
2\end{array}$ \\
\hline & Q9GZZ9 & UBA5 & UBA5 & $\begin{array}{c}\text { Ubiquitin-like modifier-activating } \\
\text { enzyme } 5\end{array}$ \\
\hline & P61088 & UBE2N & UBE2N & $\begin{array}{l}\text { Ubiquitin-conjugating enzyme E2 } \\
\mathrm{N}\end{array}$ \\
\hline \multirow{7}{*}{$\begin{array}{l}\text { Proteins without } \\
\text { Protein Family } \\
\text { assigned }\end{array}$} & P05165 & PCCA & PCCA & $\begin{array}{c}\text { Propionyl-CoA carboxylase alpha } \\
\text { chain }\end{array}$ \\
\hline & P48426 & $\mathrm{PI} 42 \mathrm{~A}$ & PIP4K2A & $\begin{array}{l}\text { Phosphatidylinositol 5-phosphate } \\
\text { 4-kinase type-2 alpha }\end{array}$ \\
\hline & P49915 & GUAA & GMPS & GMP synthase \\
\hline & Q02790 & FKBP4 & FKBP4 & $\begin{array}{c}\text { Peptidyl-prolyl cis-trans isomerase } \\
\text { FKBP4 }\end{array}$ \\
\hline & Q12905 & ILF2 & ILF2 & $\begin{array}{c}\text { Interleukin enhancer-binding } \\
\text { factor } 2 \\
\end{array}$ \\
\hline & Q14166 & TTL12 & TTLL12 & $\begin{array}{l}\text { Tubulin--tyrosine ligase-like } \\
\text { protein } 12 \\
\end{array}$ \\
\hline & Q9UHD1 & CHRD1 & CHORDC1 & $\begin{array}{c}\text { Cysteine and histidine-rich } \\
\text { domain-containing protein } 1\end{array}$ \\
\hline \multirow{12}{*}{$\begin{array}{l}\text { Other ATP-binding } \\
\text { Proteins }\end{array}$} & Q9Y6K5 & OAS3 & OAS3 & 2'-5'-oligoadenylate synthase 3 b \\
\hline & P00966 & ASSY & ASS1 & Argininosuccinate synthase \\
\hline & O43681 & ASNA & ASNA1 & ATPase ASNA1 \\
\hline & 060488 & ACSL4 & ACSL4 & $\begin{array}{l}\text { Long-chain-fatty-acid--CoA ligase } \\
4\end{array}$ \\
\hline & $\mathrm{P} 16615$ & AT2A2 & ATP2A2 & $\begin{array}{l}\text { Sarcoplasmic/endoplasmic } \\
\text { reticulum calcium ATPase } 2\end{array}$ \\
\hline & P10809 & $\mathrm{CH} 60$ & HSPD1 & $60 \mathrm{kDa}$ heat shock protein \\
\hline & $\mathrm{P} 17812$ & PYRG1 & CTPS1 & CTP synthase 1 \\
\hline & Q13057 & COASY & COASY & Bifunctional coenzyme A synthase \\
\hline & P22102 & PUR2 & GART & $\begin{array}{l}\text { Trifunctional purine biosynthetic } \\
\text { protein adenosine-3 }\end{array}$ \\
\hline & P00367 & DHE3 & GLUD1 & Glutamate dehydrogenase 1 \\
\hline & P54886 & P5CS & ALDH18A1 & $\begin{array}{c}\text { Delta-1-pyrroline-5-carboxylate } \\
\text { synthase }\end{array}$ \\
\hline & P19367 & HXK1 & HK1 & Hexokinase-1 \\
\hline
\end{tabular}




\begin{tabular}{|c|c|c|c|c|}
\hline P12956 & XRCC6 & XRCC6 & $\begin{array}{c}\text { X-ray repair cross-complementing } \\
\text { protein 6 }\end{array}$ \\
\cline { 2 - 5 } & P13010 & XRCC5 & XRCC5 & $\begin{array}{c}\text { X-ray repair cross-complementing } \\
\text { protein 5 }\end{array}$ \\
\hline P15531 & NDKA & NME1 & $\begin{array}{c}\text { Nucleoside diphosphate kinase A } \\
\text { b }\end{array}$ \\
\hline P36776 & LONM & LONP1 & Lon protease homolog \\
\hline Q9NSD9 & SYFB & FARSB & $\begin{array}{c}\text { Phenylalanine--tRNA ligase beta } \\
\text { subunit }\end{array}$ \\
\hline P00558 & PGK1 & PGK1 & Phosphoglycerate kinase 1 \\
\hline P14618 & KPYM & PKM & Pyruvate kinase PKM \\
\hline P22234 & PUR6 & PAICS & Multifunctional protein ADE2 \\
\hline P11586 & C1TC & MTHFD1 & C-1-tetrahydrofolate synthase \\
\hline O43615 & TIM44 & TIMM44 & $\begin{array}{c}\text { Mitochondrial import inner } \\
\text { membrane translocase subunit } \\
\text { TIM44 }\end{array}$ \\
\hline Q12965 & MYO1E & MYO1E & Unconventional myosin-le \\
\hline Q9NTK5 & OLA1 & OLA1 & Obg-like ATPase 1 \\
\hline
\end{tabular}

a Uniprot Code according to Uniprot Knowledge base. Proteins only with a standard deviation lower than $30 \%$ and quantified in at least 2 biological replicates.

b Proteins annotated as ATP-binding proteins in Uniprot database that were found in this study to be less abundant during macrophage interaction with $C$. albicans.

c Proteins annotated as ATP-binding proteins in Uniprot database that were found in this study to be more abundant during macrophage interaction with $C$. albicans.

Table 3. List of phosphopeptides differentially abundant after 3 hours of macrophage - $C$. albicans interaction.

\begin{tabular}{|c|c|c|c|c|c|c|}
\hline $\begin{array}{l}\text { UniProt } \\
\text { Code }^{\mathrm{a}}\end{array}$ & $\begin{array}{c}\text { Gene } \\
\text { names }\end{array}$ & Protein names ${ }^{a}$ & Phosphopeptide & Phosphosite ${ }^{b}$ & Ratio $^{c}$ & SD ${ }^{c}$ \\
\hline Q13131 & PRKAA1 & $\begin{array}{l}\text { 5'-AMP-activated } \\
\text { protein kinase } \\
\text { catalytic subunit } \\
\text { alpha-1 }\end{array}$ & SGSVSNYR & ambiguous & 1.58 & 0.22 \\
\hline Q9NWW5 & CLN6 & $\begin{array}{l}\text { Ceroid- } \\
\text { lipofuscinosis } \\
\text { neuronal protein } 6\end{array}$ & $\mathrm{HGs}^{*} \mathrm{VSADEAAR}^{\mathrm{d}}$ & Ser31 & 1.40 & 0.29 \\
\hline Q9BTU6 & PI4K2A & $\begin{array}{l}\text { Phosphatidylinositol } \\
\text { 4-kinase type 2- } \\
\text { alpha }\end{array}$ & SSSESYTQSFQSr & ambiguous & 0.70 & 0.22 \\
\hline P12931 & SRC & $\begin{array}{l}\text { Proto-oncogene } \\
\text { tyrosine-protein } \\
\text { kinase Src }\end{array}$ & LIEDNEy*TAR & Tyr419 & 0.69 & 0.22 \\
\hline Q05655 & PRKCD & $\begin{array}{l}\text { Protein kinase C } \\
\text { delta type }\end{array}$ & SDSASSEPVGIYQGFEK & ambiguous & 0.57 & 0.06 \\
\hline
\end{tabular}




\footnotetext{
a Protein name and Uniprot Code according to Uniprot Knowledge base.

b Phosphosites were considered ambiguous in case PhosphoRS algorithm assigned a localization probability lower than $75 \%$ or if it was assigned in distinct sites in different biological replicates.

${ }^{c}$ Average abundance ratio from macrophages $+C$. albicans versus control macrophages and respective inter-replicate standard deviation (cut-off in 0.3). Only phosphopeptides with a standard deviation lower than $30 \%$ and quantified in at least 2 biological replicates.

${ }^{d}$ Asterisk indicates the phosphorylation site and the corresponding aminoacid is in lower case.
}

\section{ASSOCIATED CONTENT \\ Supporting Information}

Figure S1. Schematic workflow of the experiment performed.

Figure S2. Venn diagram showing the identified proteins in each replicate.

Figure S3. GO analysis of proteins quantified after ATP-binding proteins enrichment.

Figure S4. Histogram showing $\log _{2}$-transformed mean of THP-1 macrophage protein abundance ratios upon C. albicans interaction.

Figure S5. Histogram showing $\log _{2}$-transformed mean of THP-1 macrophage

phosphopeptide abundance ratios upon C. albicans interaction.

Figure S6. Mass spectra of the differentially abundant phosphopeptides.

Figure S7. Quantification of P-ERK1/2 by Western blotting.

Figure S8. Calibration curve of the peptide FMQASEDLLK from NDKA protein.

Table S1. List of proteins identified in THP-1 macrophages after interaction with

C. albicans.

Table S2. List of proteins quantified in THP-1 macrophages after interaction with

C. albicans.

Table S3. GO analysis of the proteins from our dataset annotated in Uniprot as "ATP binding protein". 
Table S4. List of phosphopeptides quantified in THP-1 macrophages after interaction with C. albicans.

Table S5. Calibration curve of the heavy peptide and endogenous peptide quantification by SRM.

\section{AUTHOR INFORMATION}

\section{Corresponding Author}

* Lucia Monteoliva: e-mail: luciamon@ucm.es; phone: +34913941748; Fax: $+34913941745$

\section{Present Addresses}

† Singapore Immunology Network (SIgN), A*STAR; 8A Biomedical Grove, Level 4, Immunos (Biopolis), Singapore, 138648, Singapore

\section{Author Contributions}

The manuscript was written through contributions of all authors. All authors have given approval to the final version of the manuscript.

\section{Notes}

The authors declare no competing financial interest.

\section{ACKNOWLEDGEMENTS}

This study was supported by the Marie Curie Initial Training Network (FP7-PEOPLE2013-ITN ImResFun), the project BIO2015-65147-R from Spanish Ministry of Economy and Competitiveness (MINECO), InGEMICS-CM B2017/BMD-3691 from 
the Comunidad de Madrid, Spanish Network for the Research in Infectious Diseases (REIPI RD16/0016/0011) and PRB3 (PT17/0019/0012) from the ISCIII. InGEMICSCM, REIPI and PRB3 are co-financed by European Development Regional Fund ERDF "A way to achieve Europe". These results are lined up with the Human Infectious Diseases HPP initiative from the Human Proteome Project (HID-HPP). he ESEM was performed in Museo Nacional de Ciencias Naturales. The proteomics analyses were performed in Centro de Investigaciones Biológicas (CIB) and Proteomics Facility of Complutense University of Madrid (UCM), both members of ProteoRed-ISCIII network. The miRNA analysis was carried out in Genomics Facility of Complutense University of Madrid. The authors would like to thank Leif Schauser and Nitesh Kumar Singh from QIAGEN (Aarhus) IMRESFUN consortium partners for their help in IPA analysis.

\author{
ABBREVIATIONS \\ CLRs - c-type lectin receptors, DMEM - Dulbecco's modified eagle's medium, ELISA \\ - enzyme-linked immunosorbent assay, ESEM - environmental scanning electron \\ microscopy, FBS - fetal bovine serum, GO - gene ontology, IFNs - interferons, IL - \\ interleukin, IPA - Ingenuity Pathway Analysis, LDH - lactate dehydrogenase, LPS - \\ lipopolysaccharide, MOI - multiplicity of infection, NODs - nod-like receptors, PBS - \\ phosphate buffer saline, PMA - phorbol 12-myristate 13-acetate, PRRs - pattern \\ recognition receptors, RIPA - radio immunoprecipitation assay buffer, ROS - reactive \\ oxygen species, RT-PCR - real time polymerase chain reaction, SD - standard \\ deviation, STE - ser/thr protein kinase family, TLRs - toll-like receptors, TR - \\ transcription regulator, YPD - Yeast peptone dextrose
}




\section{REFERENCES}

1. Erwig, L. P.;Gow, N. A. Interactions of fungal pathogens with phagocytes. Nature reviews. Microbiology 2016, 14 (3), 163-76.

2. Pfaller, M. A.;Castanheira, M. Nosocomial Candidiasis: Antifungal Stewardship and the Importance of Rapid Diagnosis. Medical mycology 2016, 54 (1), 1-22.

3. Nieto, M. C.; Telleria, O.;Cisterna, R. Sentinel surveillance of invasive candidiasis in Spain: epidemiology and antifungal susceptibility. Diagnostic microbiology and infectious disease 2015, 81 (1), 34-40.

4. Bourgeois, C.; Majer, O.; Frohner, I. E.; Tierney, L.;Kuchler, K. Fungal attacks on mammalian hosts: pathogen elimination requires sensing and tasting. Current opinion in microbiology 2010, 13 (4), 401-8.

5. West, A. P.; Koblansky, A. A.;Ghosh, S. Recognition and signaling by toll-like receptors. Annual review of cell and developmental biology 2006, 22, 409-37.

6. Reales-Calderon, J. A.; Martinez-Solano, L.; Martinez-Gomariz, M.; Nombela, C.; Molero, G.;Gil, C. Sub-proteomic study on macrophage response to Candida albicans unravels new proteins involved in the host defense against the fungus. Journal of proteomics 2012, 75 (15), 4734-46.

7. Reales-Calderon, J. A.; Sylvester, M.; Strijbis, K.; Jensen, O. N.; Nombela, C.; Molero, G.;Gil, C. Candida albicans induces pro-inflammatory and anti-apoptotic signals in macrophages as revealed by quantitative proteomics and phosphoproteomics. Journal of proteomics 2013, 91, 106-35.

8. Reales-Calderon, J. A.; Aguilera-Montilla, N.; Corbi, A. L.; Molero, G.;Gil, C. Proteomic characterization of human proinflammatory M1 and anti-inflammatory M2 macrophages and their response to Candida albicans. Proteomics 2014, 14 (12), 150318. 
9. Shin, Y. K.; Kim, K. Y.;Paik, Y. K. Alterations of protein expression in macrophages in response to Candida albicans infection. Mol Cells 2005, 20 (2), 271-9.

10. Kitahara, N.; Morisaka, H.; Aoki, W.; Takeda, Y.; Shibasaki, S.; Kuroda, K.;Ueda, M. Description of the interaction between Candida albicans and macrophages by mixed and quantitative proteome analysis without isolation. Amb Express 2015, 5 (41), 1-12.

11. Xiao, Y.;Wang, Y. Global discovery of protein kinases and other nucleotidebinding proteins by mass spectrometry. Mass spectrometry reviews 2014, 35, 601-619. 12. Guo, L.; Xiao, Y.; Fan, M.; Li, J. J.;Wang, Y. Profiling Global Kinome Signatures of the Radioresistant MCF-7/C6 Breast Cancer Cells Using MRM-based Targeted Proteomics. Journal of proteome research 2014.

13. Wolfe, L. M.; Veeraraghavan, U.; Idicula-Thomas, S.; Schurer, S.; Wennerberg, K.; Reynolds, R.; Besra, G. S.;Dobos, K. M. A chemical proteomics approach to profiling the ATP-binding proteome of Mycobacterium tuberculosis. Molecular \& cellular proteomics : MCP 2013, 12 (6), 1644-60.

14. Villamor, J. G.; Kaschani, F.; Colby, T.; Oeljeklaus, J.; Zhao, D.; Kaiser, M.; Patricelli, M. P.;van der Hoorn, R. A. Profiling protein kinases and other ATP binding proteins in Arabidopsis using Acyl-ATP probes. Molecular \& cellular proteomics : MCP 2013, 12 (9), 2481-96.

15. Adachi, J.; Kishida, M.; Watanabe, S.; Hashimoto, Y.; Fukamizu, K.;Tomonaga, T. Proteome-Wide Discovery of Unknown ATP-Binding Proteins and Kinase Inhibitor Target Proteins Using an ATP Probe (vol 13, pg 5461, 2014). Journal of proteome research 2015, 14 (2), 1333-1333.

16. Xiao, Y.; Guo, L.;Wang, Y. Isotope-coded ATP probe for quantitative affinity profiling of ATP-binding proteins. Analytical chemistry 2013, 85 (15), 7478-86. 
17. Graves, P. R.; Kwiek, J. J.; Fadden, P.; Ray, R.; Hardeman, K.; Coley, A. M.; Foley, M.;Haystead, T. A. Discovery of novel targets of quinoline drugs in the human purine binding proteome. Molecular pharmacology 2002, 62 (6), 1364-72.

18. Daub, H.; Olsen, J. V.; Bairlein, M.; Gnad, F.; Oppermann, F. S.; Korner, R.; Greff, Z.; Keri, G.; Stemmann, O.;Mann, M. Kinase-selective enrichment enables quantitative phosphoproteomics of the kinome across the cell cycle. Molecular cell 2008, $31(3), 438-48$.

19. Hanoulle, X.; Van Damme, J.; Staes, A.; Martens, L.; Goethals, M.; Vandekerckhove, J.;Gevaert, K. A new functional, chemical proteomics technology to identify purine nucleotide binding sites in complex proteomes. Journal of proteome research 2006, 5 (12), 3438-45.

20. Duncan, J. S.; Whittle, M. C.; Nakamura, K.; Abell, A. N.; Midland, A. A.; Zawistowski, J. S.; Johnson, N. L.; Granger, D. A.; Jordan, N. V.; Darr, D. B.; Usary, J.; Kuan, P. F.; Smalley, D. M.; Major, B.; He, X.; Hoadley, K. A.; Zhou, B.; Sharpless, N. E.; Perou, C. M.; Kim, W. Y.; Gomez, S. M.; Chen, X.; Jin, J.; Frye, S. V.; Earp, H. S.; Graves, L. M.;Johnson, G. L. Dynamic reprogramming of the kinome in response to targeted MEK inhibition in triple-negative breast cancer. Cell 2012, 149 (2), 307-21.

21. Patricelli, M. P.; Szardenings, A. K.; Liyanage, M.; Nomanbhoy, T. K.; Wu, M.; Weissig, H.; Aban, A.; Chun, D.; Tanner, S.;Kozarich, J. W. Functional Interrogation of the Kinome Using Nucleotide Acyl Phosphates. The Biochemical journal 2007, 46, 350-358.

22. Ong, S. E.;Mann, M. A practical recipe for stable isotope labeling by amino acids in cell culture (SILAC). Nature protocols 2006, 1 (6), 2650-60. 
23. Blagoev, B.; Kratchmarova, I.; Ong, S. E.; Nielsen, M.; Foster, L. J.;Mann, M. A proteomics strategy to elucidate functional protein-protein interactions applied to EGF signaling. Nature biotechnology 2003, 21 (3), 315-8.

24. Huang, J.; Wang, F.; Ye, M.;Zou, H. Enrichment and separation techniques for large-scale proteomics analysis of the protein post-translational modifications. Journal of chromatography. A 2014, 1372C, 1-17.

25. Reales-Calderon, J. A.; Vaz, C.; Monteoliva, L.; Molero, G.;Gil, C. Candida albicans Modifies the Protein Composition and Size Distribution of THP1 macrophages-derived Extracellular Vesicles. Journal of proteome research 2016, 16 (1), 87-105.

26. Fernandez-Arenas, E.; Cabezon, V.; Bermejo, C.; Arroyo, J.; Nombela, C.; Diez-Orejas, R.;Gil, C. Integrated proteomics and genomics strategies bring new insight into Candida albicans response upon macrophage interaction. Molecular \& cellular proteomics : MCP 2007, 6 (3), 460-78.

27. Bonzon-Kulichenko, E.; Perez-Hernandez, D.; Nunez, E.; Martinez-Acedo, P.; Navarro, P.; Trevisan-Herraz, M.; Ramos Mdel, C.; Sierra, S.; Martinez-Martinez, S.; Ruiz-Meana, M.; Miro-Casas, E.; Garcia-Dorado, D.; Redondo, J. M.; Burgos, J. S.;Vazquez, J. A robust method for quantitative high-throughput analysis of proteomes by $18 \mathrm{O}$ labeling. Molecular \& cellular proteomics : MCP 2011, 10 (1), M110 003335.

28. Shevchenko, A.; Tomas, H.; Havlis, J.; Olsen, J. V.;Mann, M. In-gel digestion for mass spectrometric characterization of proteins and proteomes. Nature protocols 2006, 1 (6), 2856-60.

29. Picotti, P.;Aebersold, R. Selected reaction monitoring-based proteomics: workflows, potential, pitfalls and future directions. Nature methods 2012, 9 (6), 555-66. 
30. Carmona-Saez, P.; Chagoyen, M.; Tirado, F.; Carazo, J. M.;Pascual-Montano, A. GENECODIS: a web-based tool for finding significant concurrent annotations in gene lists. Genome Biol 2007, 8 (1), R3.

31. Nogales-Cadenas, R.; Carmona-Saez, P.; Vazquez, M.; Vicente, C.; Yang, X.; Tirado, F.; Carazo, J. M.;Pascual-Montano, A. GeneCodis: interpreting gene lists through enrichment analysis and integration of diverse biological information. Nucleic acids research 2009, 37 (Web Server issue), W317-22.

32. Tabas-Madrid, D.; Nogales-Cadenas, R.;Pascual-Montano, A. GeneCodis3: a non-redundant and modular enrichment analysis tool for functional genomics. Nucleic acids research 2012, 40 (Web Server issue), W478-83.

33. Szklarczyk, D.; Morris, J. H.; Cook, H.; Kuhn, M.; Wyder, S.; Simonovic, M.; Santos, A.; Doncheva, N. T.; Roth, A.; Bork, P.; Jensen, L. J.;von Mering, C. The STRING database in 2017: quality-controlled protein-protein association networks, made broadly accessible. Nucleic acids research 2017, 45 (D1), D362-D368.

34. Livak, K. J.;Schmittgen, T. D. Analysis of relative gene expression data using real-time quantitative PCR and the 2(-Delta Delta C(T)) Method. Methods 2001, 25 (4), $402-8$

35. Fernandez-Arenas, E.; Bleck, C. K.; Nombela, C.; Gil, C.; Griffiths, G.;DiezOrejas, R. Candida albicans actively modulates intracellular membrane trafficking in mouse macrophage phagosomes. Cellular microbiology 2009, 11 (4), 560-89.

36. Traba, J.; Del Arco, A.; Duchen, M. R.; Szabadkai, G.;Satrustegui, J. SCaMC-1 promotes cancer cell survival by desensitizing mitochondrial permeability transition via ATP/ADP-mediated matrix Ca(2+) buffering. Cell Death Differ 2012, 19 (4), 650-60.

37. Shiota, M.; Izumi, H.; Miyamoto, N.; Onitsuka, T.; Kashiwagi, E.; Kidani, A.; Hirano, G.; Takahashi, M.; Ono, M.; Kuwano, M.; Naito, S.; Sasaguri, Y.;Kohno, K. 
Ets regulates peroxiredoxin 1 and 5 expressions through their interaction with the highmobility group protein B1. Cancer Sci 2008, 99 (10), 1950-9.

38. Wang, Q.; Sawyer, I. A.; Sung, M. H.; Sturgill, D.; Shevtsov, S. P.; Pegoraro, G.; Hakim, O.; Baek, S.; Hager, G. L.;Dundr, M. Cajal bodies are linked to genome conformation. Nat Commun 2016, 7, 10966.

39. Arthur, J. S.;Ley, S. C. Mitogen-activated protein kinases in innate immunity. Nature reviews. Immunology 2013, 13 (9), 679-92.

40. Yuan, J.; Murrell, G. A.; Trickett, A.; Landtmeters, M.; Knoops, B.;Wang, M. X. Overexpression of antioxidant enzyme peroxiredoxin 5 protects human tendon cells against apoptosis and loss of cellular function during oxidative stress. Biochim Biophys Acta 2004, 1693 (1), 37-45.

41. Jang, J. Y.; Choi, Y.; Jeon, Y. K.;Kim, C. W. Suppression of adenine nucleotide translocase-2 by vector-based siRNA in human breast cancer cells induces apoptosis and inhibits tumor growth in vitro and in vivo. Breast Cancer Res 2008, 10 (1), R11.

42. Lee, J. H.; Choi, Y. J.; Park, S. H.;Nam, M. J. Potential role of nucleoside diphosphate kinase in myricetin-induced selective apoptosis in colon cancer HCT15cells. Food Chem Toxicol 2018, 116 (Pt B), 315-322.

43. Liu, Q. Y.; Lei, J. X.; LeBlanc, J.; Sodja, C.; Ly, D.; Charlebois, C.; Walker, P. R.; Yamada, T.; Hirohashi, S.;Sikorska, M. Regulation of DNaseY activity by actininalpha4 during apoptosis. Cell Death Differ 2004, 11 (6), 645-54.

44. Lee, K. K.; Ohyama, T.; Yajima, N.; Tsubuki, S.;Yonehara, S. MST, a physiological caspase substrate, highly sensitizes apoptosis both upstream and downstream of caspase activation. The Journal of biological chemistry 2001, 276 (22), $19276-85$. 
45. Shalini, S.; Dorstyn, L.; Dawar, S.;Kumar, S. Old, new and emerging functions of caspases. Cell Death Differ 2015, 22 (4), 526-39.

46. Uwamahoro, N.; Verma-Gaur, J.; Shen, H. H.; Qu, Y.; Lewis, R.; Lu, J.; Bambery, K.; Masters, S. L.; Vince, J. E.; Naderer, T.;Traven, A. The pathogen Candida albicans hijacks pyroptosis for escape from macrophages. MBio 2014, 5 (2), e00003-14.

47. Bergsbaken, T.; Fink, S. L.;Cookson, B. T. Pyroptosis: host cell death and inflammation. Nature reviews. Microbiology 2009, 7 (2), 99-109.

48. Tsitsiou, E.;Lindsay, M. A. microRNAs and the immune response. Curr Opin Pharmacol 2009, 9 (4), 514-20.

49. Taganov, K. D.; Boldin, M. P.; Chang, K. J.;Baltimore, D. NF-kappaBdependent induction of microRNA miR-146, an inhibitor targeted to signaling proteins of innate immune responses. Proceedings of the National Academy of Sciences of the United States of America 2006, 103 (33), 12481-6.

50. Agustinho, D. P.; de Oliveira, M. A.; Tavares, A. H.; Derengowski, L.; Stolz, V.; Guilhelmelli, F.; Mortari, M. R.; Kuchler, K.;Silva-Pereira, I. Dectin-1 is required for miR155 upregulation in murine macrophages in response to Candida albicans. Virulence 2016, 1-12.

51. Monk, C. E.; Hutvagner, G.;Arthur, J. S. Regulation of miRNA transcription in macrophages in response to Candida albicans. PloS one 2010, 5 (10), e13669.

52. Pappas, P. G.; Lionakis, M. S.; Arendrup, M. C.; Ostrosky-Zeichner, L.;Kullberg, B. J. Invasive candidiasis. Nat Rev Dis Primers 2018, 4, 18026.

53. Carpino, N.; Naseem, S.; Frank, D. M.;Konopka, J. B. Modulating Host Signaling Pathways to Promote Resistance to Infection by Candida albicans. Frontiers in cellular and infection microbiology 2017, 7, 481. 
54. Zwolanek, F.; Riedelberger, M.; Stolz, V.; Jenull, S.; Istel, F.; Koprulu, A. D.; Ellmeier, W.;Kuchler, K. The non-receptor tyrosine kinase Tec controls assembly and activity of the noncanonical caspase-8 inflammasome. PLoS pathogens 2014, 10 (12), e1004525.

55. Singh, A. K.; Pandey, R. K.; Siqueira-Neto, J. L.; Kwon, Y. J.; Freitas, L. H.; Shaha, C.;Madhubala, R. Proteomic-Based Approach To Gain Insight into Reprogramming of THP-1 Cells Exposed to Leishmania donovani over an Early Temporal Window. Infection and immunity 2015, 83 (5), 1853-1868.

56. Duan, Z.; Chen, X.; Du, L.; Liu, C.; Zeng, R.; Chen, Q.;Li, M. Inflammation Induced by Candida parapsilosis in THP-1 Cells and Human Peripheral Blood Mononuclear Cells (PBMCs). Mycopathologia 2017, 182 (11-12), 1015-1023.

57. Kaewseekhao, B.; Naranbhai, V.; Roytrakul, S.; Namwat, W.; Paemanee, A.; Lulitanond, V.; Chaiprasert, A.;Faksri, K. Comparative Proteomics of Activated THP-1 Cells Infected with Mycobacterium tuberculosis Identifies Putative Clearance Biomarkers for Tuberculosis Treatment. PloS one 2015, 10 (7), e 0134168.

58. Barker, K. S.; Liu, T.;Rogers, P. D. Coculture of THP-1 human mononuclear cells with Candida albicans results in pronounced changes in host gene expression. The Journal of infectious diseases 2005, 192 (5), 901-12.

59. Chanput, W.; Mes, J. J.;Wichers, H. J. THP-1 cell line: An in vitro cell model for immune modulation approach. International immunopharmacology 2014, 23 (1), $37-45$.

60. Lemeer, S.; Zorgiebel, C.; Ruprecht, B.; Kohl, K.;Kuster, B. Comparing immobilized kinase inhibitors and covalent ATP probes for proteomic profiling of kinase expression and drug selectivity. Journal of proteome research 2013, 12 (4), 1723-31. 
61. Oppermann, F. S.; Gnad, F.; Olsen, J. V.; Hornberger, R.; Greff, Z.; Keri, G.; Mann, M.;Daub, H. Large-scale proteomics analysis of the human kinome. Molecular \& cellular proteomics : MCP 2009, 8 (7), 1751-64.

62. Sun, G.; Yao, F.; Tian, Z.; Ma, T.;Yang, Z. A first CLN6 variant case of late infantile neuronal ceroid lipofuscinosis caused by a homozygous mutation in a boy from China: a case report. BMC Med Genet 2018, 19 (1), 177.

63. Bae, H. B.; Zmijewski, J. W.; Deshane, J. S.; Tadie, J. M.; Chaplin, D. D.; Takashima, S.;Abraham, E. AMP-activated protein kinase enhances the phagocytic ability of macrophages and neutrophils. FASEB J 2011, 25 (12), 4358-68.

64. Lizcano, J. M.; Goransson, O.; Toth, R.; Deak, M.; Morrice, N. A.; Boudeau, J.; Hawley, S. A.; Udd, L.; Makela, T. P.; Hardie, D. G.;Alessi, D. R. LKB1 is a master kinase that activates 13 kinases of the AMPK subfamily, including MARK/PAR-1. Embo Journal 2004, 23 (4), 833-843.

65. Pandey, A.; Ding, S. L.; Qin, Q. M.; Gupta, R.; Gomez, G.; Lin, F.; Feng, X.; Fachini da Costa, L.; Chaki, S. P.; Katepalli, M.; Case, E. D.; van Schaik, E. J.; Sidiq, T.; Khalaf, O.; Arenas, A.; Kobayashi, K. S.; Samuel, J. E.; Rivera, G. M.; Alaniz, R. C.; Sze, S. H.; Qian, X.; Brown, W. J.; Rice-Ficht, A.; Russell, W. K.; Ficht, T. A.;de Figueiredo, P. Global Reprogramming of Host Kinase Signaling in Response to Fungal Infection. Cell host \& microbe 2017, 21 (5), 637-649 e6.

66. Hawley, S. A.; Ross, F. A.; Gowans, G. J.; Tibarewal, P.; Leslie, N. R.;Hardie, D. G. Phosphorylation by Akt within the ST loop of AMPK-alpha 1 down-regulates its activation in tumour cells. Biochemical Journal 2014, 459, 275-287.

67. Netea, M. G.; Joosten, L. A.; van der Meer, J. W.; Kullberg, B. J.;van de Veerdonk, F. L. Immune defence against Candida fungal infections. Nature reviews. Immunology 2015, 15 (10), 630-42. 
68. Zhang, Y.; Tu, Y.; Zhao, J.; Chen, K.;Wu, C. Reversion-induced LIM interaction with Src reveals a novel Src inactivation cycle. J Cell Biol 2009, 184 (6), 785-92.

69. Byeon, S. E.; Yi, Y. S.; Oh, J.; Yoo, B. C.; Hong, S.;Cho, J. Y. The Role of Src Kinase inMacrophage-Mediated Inflammatory Responses. Mediators of inflammation 2012, 2012, 1-18.

70. Minogue, S.; Waugh, M. G.; De Matteis, M. A.; Stephens, D. J.; Berditchevski, F.;Hsuan, J. J. Phosphatidylinositol 4-kinase is required for endosomal trafficking and degradation of the EGF receptor. Journal of Cell Science 2006, 119 (3), 571-580.

71. Via, L. E.; Deretic, D.; Ulmer, R. J.; Hibler, N. S.; Huber, L. A.;Deretic, V. Arrest of mycobacterial phagosome maturation is caused by a block in vesicle fusion between stages controlled by rab5 and rab7. Journal of Biological Chemistry 1997, 272 (20), 13326-13331.

72. Vergne, I.; Fratti, R. A.; Hill, P. J.; Chua, J.; Belisle, J.;Deretic, V. Mycobacterium tuberculosis phagosome maturation arrest: mycobacterial phosphatidylinositol analog phosphatidylinositol mannoside stimulates early endosomal fusion. Mol Biol Cell 2004, 15 (2), 751-60.

73. Rothenberger, S.; Iacopetta, B. J.;Kuhn, L. C. Endocytosis of the transferrin receptor requires the cytoplasmic domain but not its phosphorylation site. Cell 1987, 49 (3), 423-31.

74. Forman, H. J.;Torres, M. Redox signaling in macrophages. Mol Aspects Med 2001, 22 (4-5), 189-216.

75. Choi, H. I.; Chung, K. J.; Yang, H. Y.; Ren, L.; Sohn, S.; Kim, P. R.; Kook, M. S.; Choy, H. E.;Lee, T. H. Peroxiredoxin V selectively regulates IL-6 production by modulating the Jak2-Stat5 pathway. Free Radic Biol Med 2013, 65, 270-9. 
76. Shui, W.; Gilmore, S. A.; Sheu, L.; Liu, J.; Keasling, J. D.;Bertozzi, C. R. Quantitative proteomic profiling of host-pathogen interactions: the macrophage response to Mycobacterium tuberculosis lipids. Journal of proteome research 2009, 8 (1), 282-9.

77. Liu, P. S.;Ho, P. C. Mitochondria: A master regulator in macrophage and T cell immunity. Mitochondrion 2017, 41 (2018), 45-50.

78. Tazi, J.; Bakkour, N.;Stamm, S. Alternative splicing and disease. Biochim Biophys Acta 2009, 1792 (1), 14-26.

79. Geuens, T.; Bouhy, D.;Timmerman, V. The hnRNP family: insights into their role in health and disease. Hum Genet 2016, 135 (8), 851-867.

80. Choi, Y. D.; Grabowski, P. J.; Sharp, P. A.;Dreyfuss, G. Heterogeneous nuclear ribonucleoproteins: role in RNA splicing. Science 1986, 231 (4745), 1534-9.

81. Mcllwain, D. R.; Berger, T.;Mak, T. W. Caspase functions in cell death and disease. Cold Spring Harbor perspectives in biology 2013, 5 (4), a008656.

82. Vylkova, S.;Lorenz, M. C. Phagosomal Neutralization by the Fungal Pathogen Candida albicans Induces Macrophage Pyroptosis. Infection and immunity 2017, 85 (2). 83. O'Meara, T. R.; Veri, A. O.; Ketela, T.; Jiang, B.; Roemer, T.;Cowen, L. E. Global analysis of fungal morphology exposes mechanisms of host cell escape. Nat Commun 2015, 6, 6741.

84. Wellington, M.; Koselny, K.;Krysan, D. J. Candida albicans morphogenesis is not required for macrophage interleukin 1beta production. MBio 2012, 4 (1), e00433-12. 85. Netea, M. G.; Brown, G. D.; Kullberg, B. J.;Gow, N. A. An integrated model of the recognition of Candida albicans by the innate immune system. Nature reviews. Microbiology 2008, 6 (1), 67-78. 
86. Kramer, A.; Green, J.; Pollard, J., Jr.;Tugendreich, S. Causal analysis approaches in Ingenuity Pathway Analysis. Bioinformatics 2014, 30 (4), 523-30.

87. Estrada-Mata, E.; Navarro-Arias, M. J.; Perez-Garcia, L. A.; Mellado-Mojica, E.; Lopez, M. G.; Csonka, K.; Gacser, A.;Mora-Montes, H. M. Members of the Candida parapsilosis Complex and Candida albicans are Differentially Recognized by Human Peripheral Blood Mononuclear Cells. Frontiers in microbiology 2015, 6, 1527.

88. Martinez-Solano, L.; Reales-Calderon, J. A.; Nombela, C.; Molero, G.;Gil, C. Proteomics of RAW 264.7 macrophages upon interaction with heat-inactivated Candida albicans cells unravel an anti-inflammatory response. Proteomics 2009, 9 (11), 29953010. 
TOC

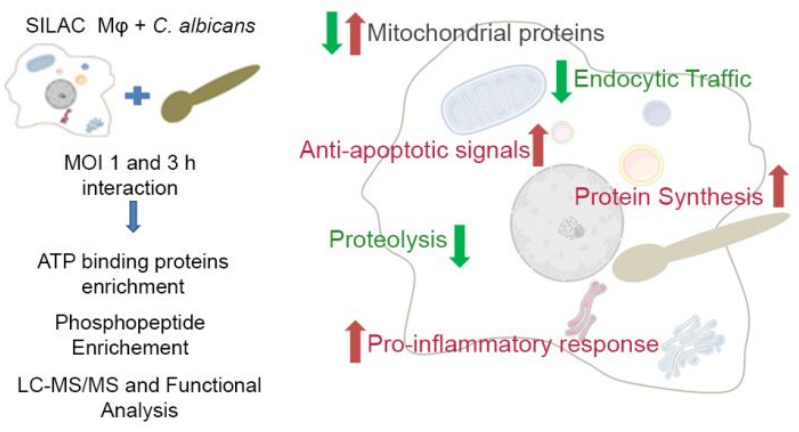


A

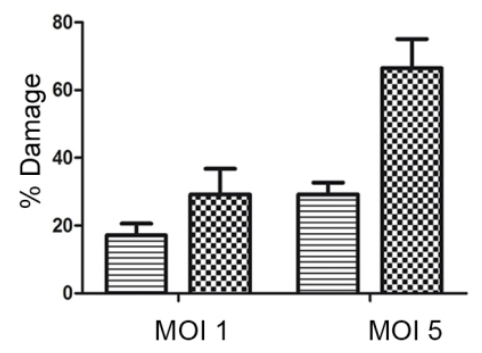

C

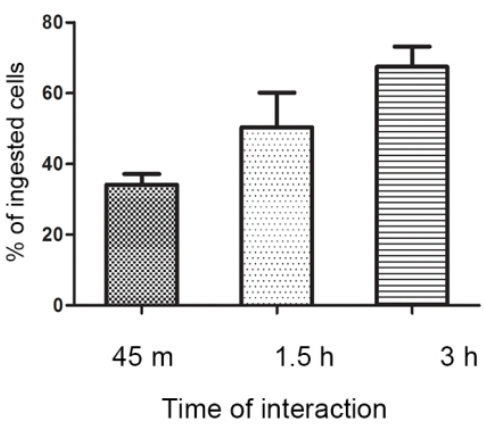

B

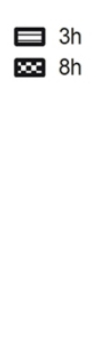

D
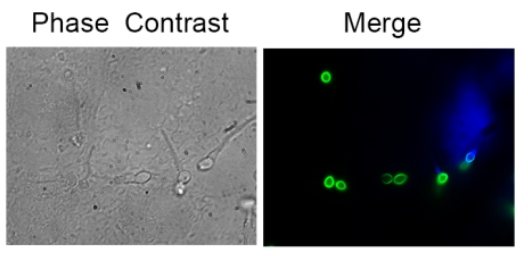

$\mathrm{M} \varphi+$ C. albicans

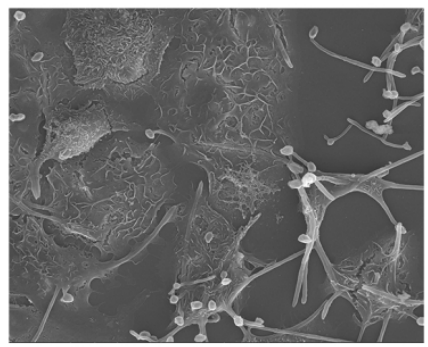

Figure 1. THP1 macrophage interaction with C. albicans cells. (A) Lactate dehydrogenase cytotoxicity assay to measure the damage of Candida cells in THP1 macrophages after $3 \mathrm{~h}$ and $8 \mathrm{~h}$ of interaction with $\mathrm{C}$. albicans cells and at a MOI of 1 and 5. (B) Fluorescence microscopy images of THP1 macrophages exposed to labeled C. albicans strain SC5314 (Oregon green 488) in green, for 3h. Intracellular and external/adhered C. albicans cells were distinguished based on fluorescence after co-staining with Calcofluor white in blue, which does not enter or stain macrophages. (C) Phagocytic activity of macrophages at different times of interaction. (D) Environmental scanning electronic microscopy (ESEM) of macrophage and C. albicans coculture after $3 \mathrm{~h}$ of interaction 
A

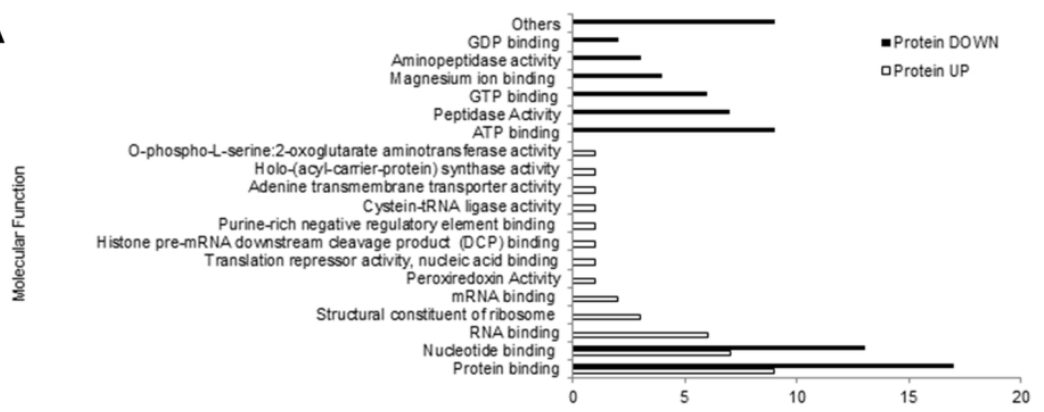

B

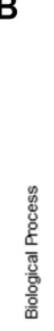

C

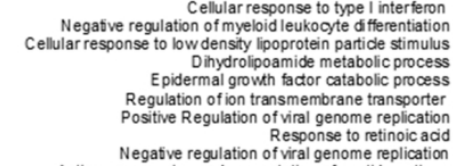

Response to retinoic acid
Negafive regulation of viral genome replication

Antigen processing and presentation of peptide antigen

Cellular nitrogen compound metabolic process

Apoptotic process
Proteolysis

Termination of RNA polymerase transcription
Viral infection cyde

Viral infection cyde
Viral transcription

Translational elongation

Translational temination
Nudear mRN Asplicing, via splicesosome
Viral Reproduction

Gene expression

\section{-}

\section{0}

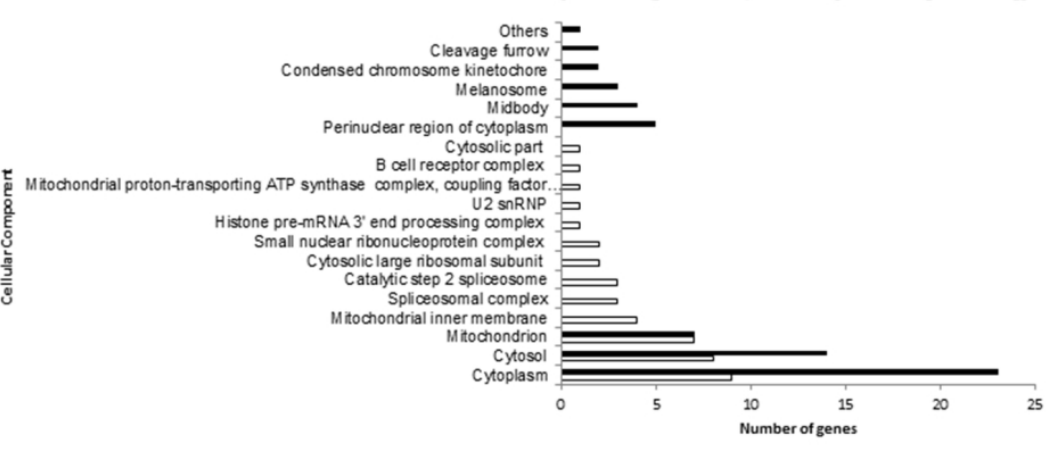

Figure 2. Gene Ontology (GO) analysis of the proteins considered differentially abundant after macrophage interaction with C. albicans. GO analysis of (A) molecular function, (B) biological process and (C) cellular component.

$140 \times 180 \mathrm{~mm}(300 \times 300 \mathrm{DPI})$ 


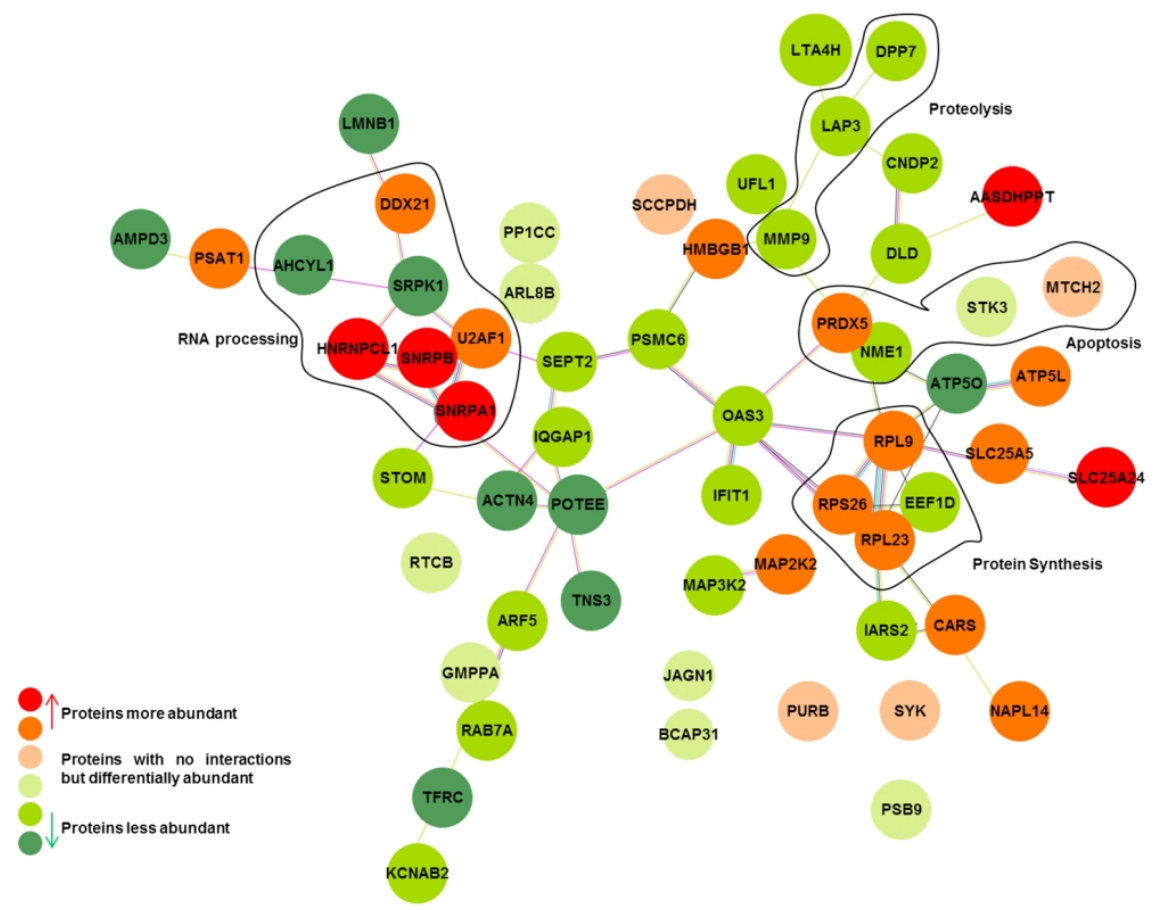

Figure 3. Predicted protein-protein interacting network using STRING (v10.0). Some biological processes (RNA splicing, protein synthesis, proteolysis, endocytic traffic and apoptosis) are highlighted in the network, signaling some of the interacting proteins that are involved in each process. The network protein-protein interaction p-value was $5.76 \mathrm{e}-05$. 
A Dual specificity mitogen-activated protein kinase kinase 2 (MAP2K2)

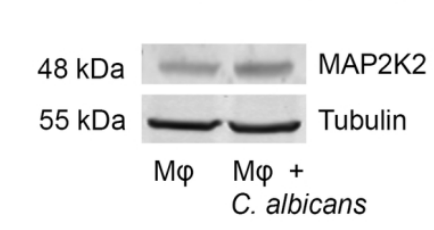

B

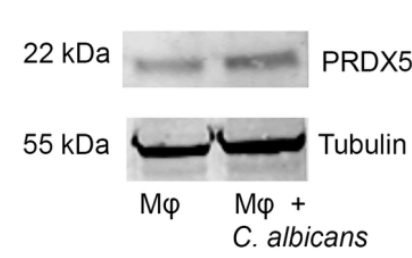

C

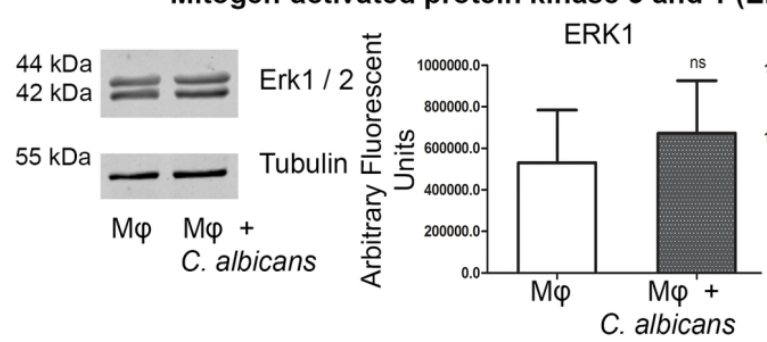

D Nucleoside disphosphate kinase A (NDKA)
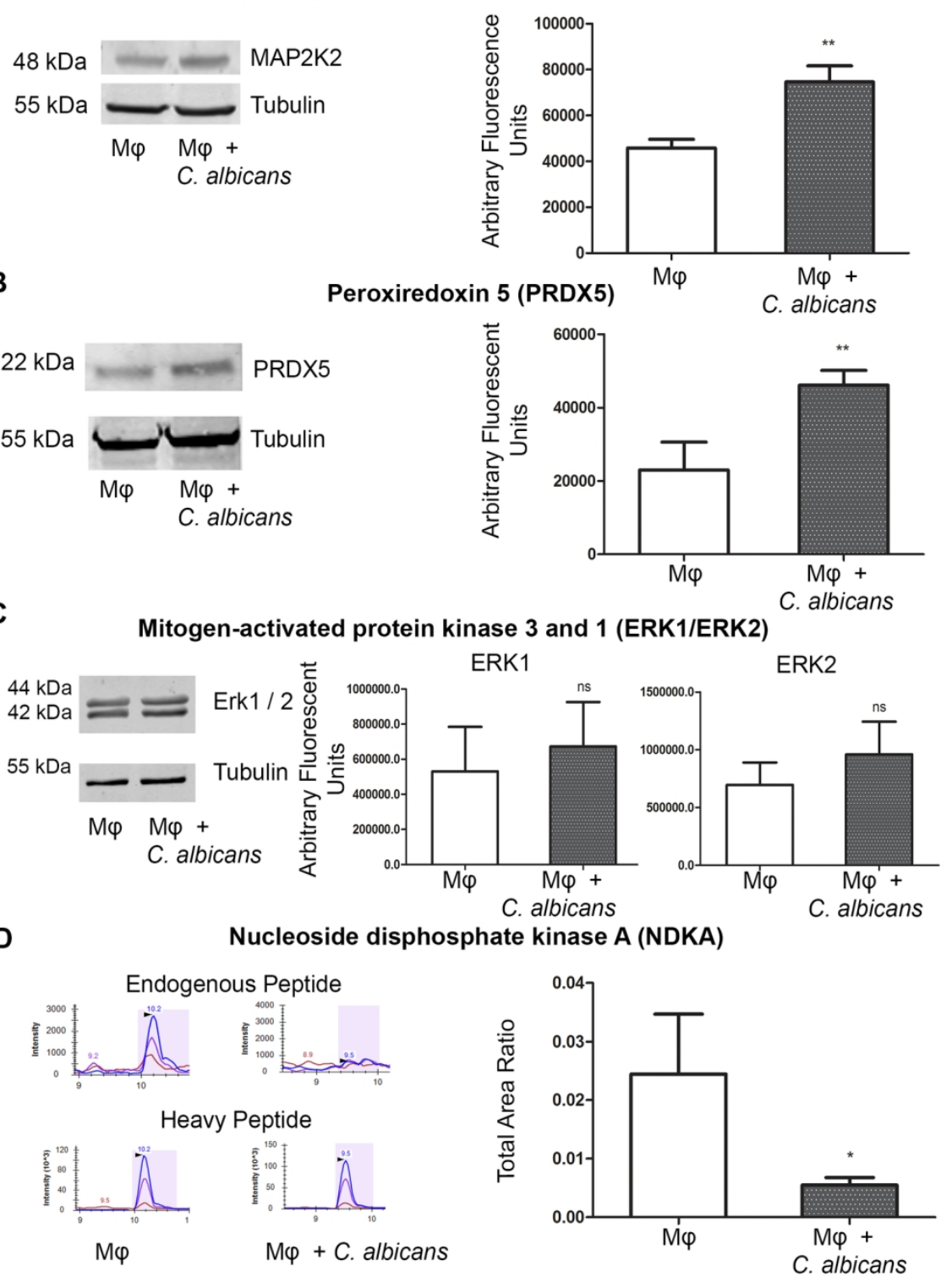

Figure 4. Proteomic results validation in both conditions: $M \varphi$ (control) and $M \varphi+C$. albicans (MOI 1 and $3 \mathrm{~h}$ of incubation). Quantification of: (A) MAP2K2, (B) PRDX5 and (C) ERK1/2 by Western blotting and (D) NDKA by selected reaction monitoring.

$140 \times 180 \mathrm{~mm}(300 \times 300$ DPI $)$ 
A

Cleaved Caspase 3

B

IL-1 $\beta$

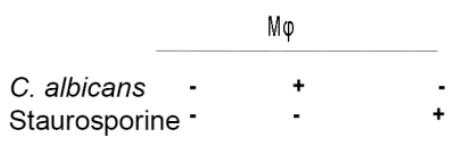

$55 \mathrm{kDa}$

$22 \mathrm{kDa}$
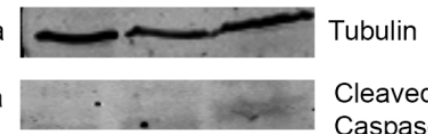

\section{Cleaved}

Caspase 3

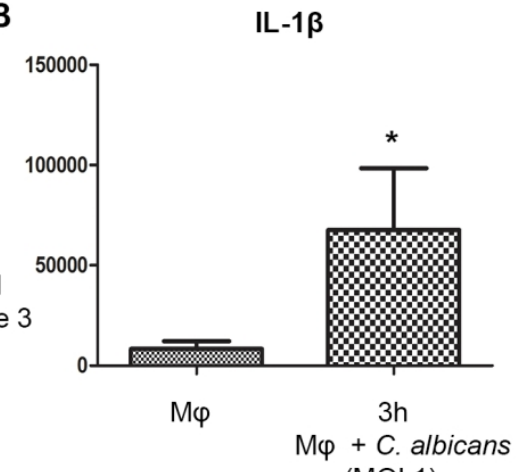

C

IL-12p40

D

(MOI 1)
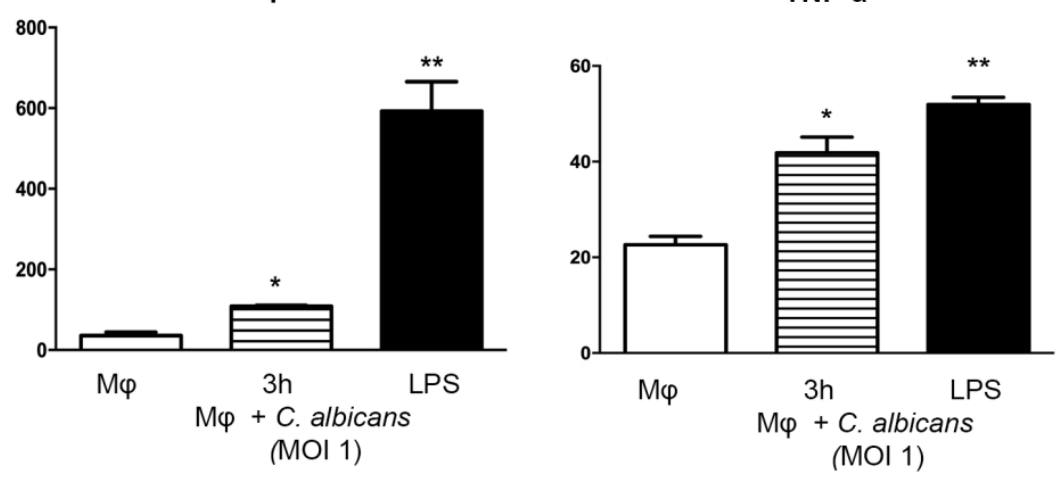

Figure 5. Caspase 3 activation and cytokine secretion measurement. Caspase activation was measured by Western blotting $(A)$ and cytokine secretion measured using Enzyme-Linked ImmunoSorbent Assay (ELISA):

(B) Il-1, , (C) IL-12p40 and (D) TNF-a secretion in $M \varphi$ (control) and $M \varphi+C$. albicans and after treatment with LPS (positive control). 


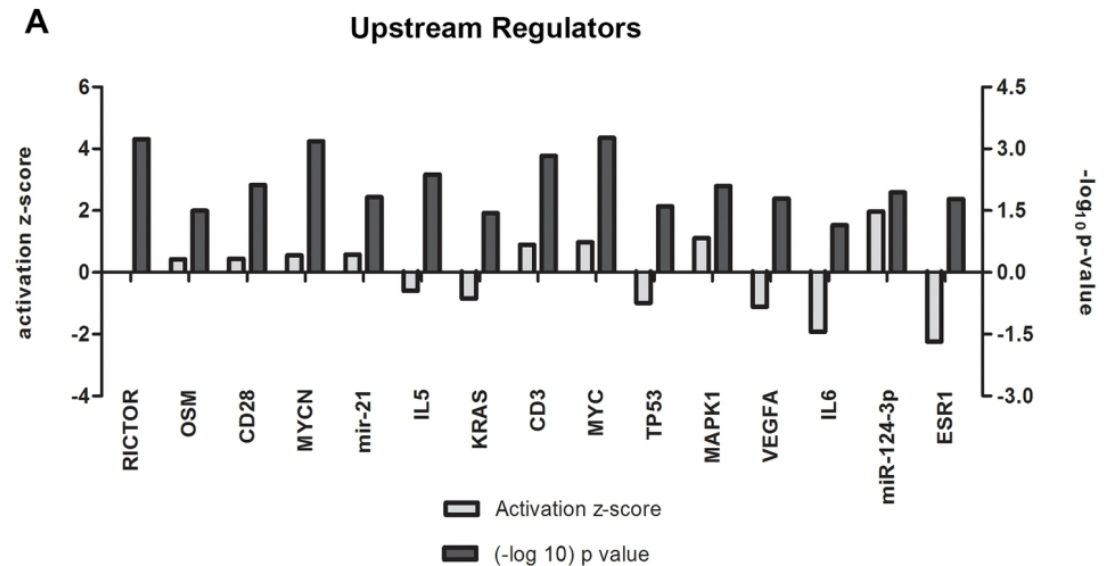

B

IL-6

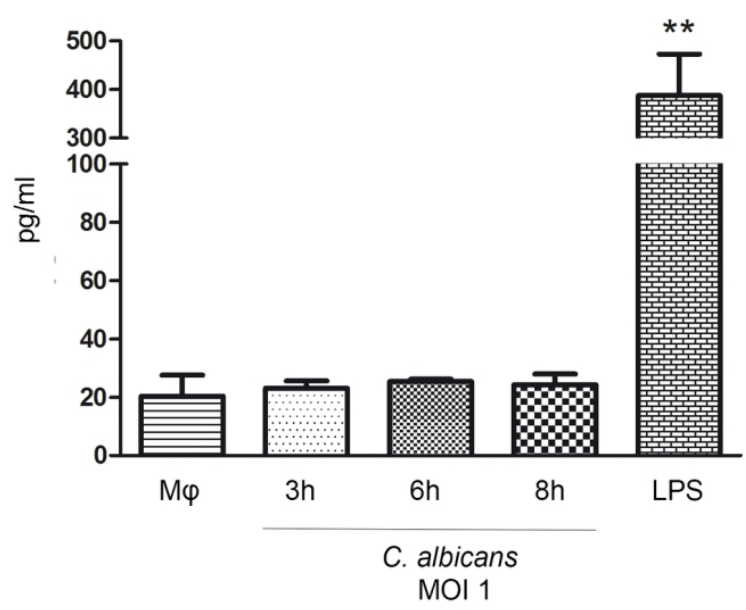

Figure 6. Upstream-regulators predicted to be implicated in the response to C. albicans using Ingenuity $\AA$ Pathway Analysis (IPA). The upstream regulators analysis is based on prior knowledge of expected effects between transcriptional regulators and their target genes stored in the IPA. (A) Bar chart of the upstream regulators that were predicted, including the activation $z$-score and $p$-value of each upstream regulator derived from IPA. Cellular validation of some of the upstream regulators was performed (B) IL-6 secretion by ELISA.

$140 \times 180 \mathrm{~mm}(300 \times 300 \mathrm{DPI})$ 
A

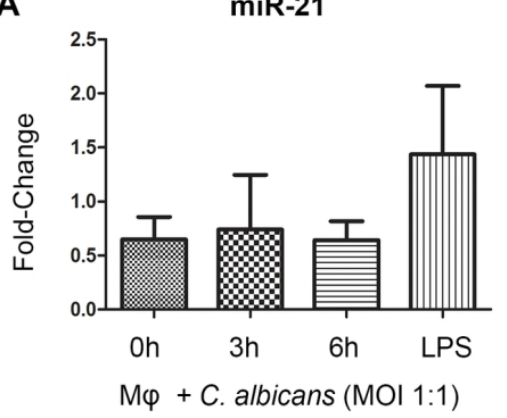

B

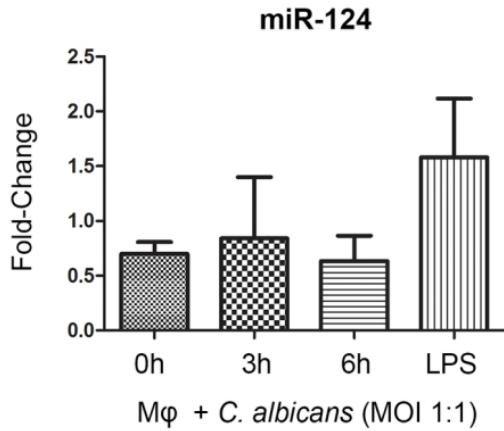

C

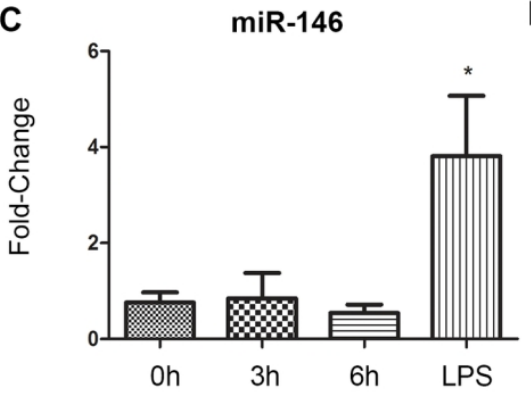

$\mathrm{M} \varphi+C$. albicans (MOI 1:1)
D

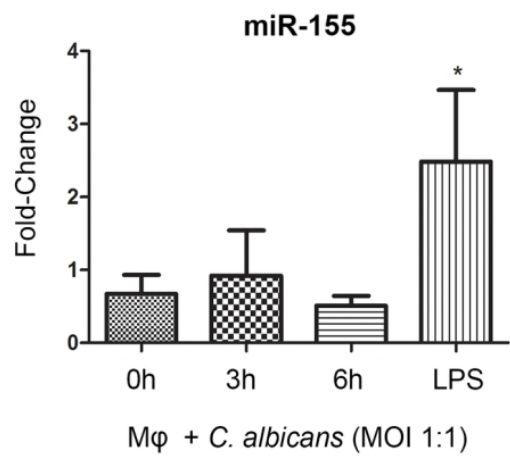

Figure 7. Expression levels of miRNAs in THP1 macrophages after interaction with C. albicans cells. Expression levels of (A) miR-21 and (B) mir-124 that were predicted by the IPA and (c) miR-146 and (D) miR-155 that were known to be activated after treatment with LPS and were used as controls.

$140 \times 180 \mathrm{~mm}(300 \times 300 \mathrm{DPI})$ 


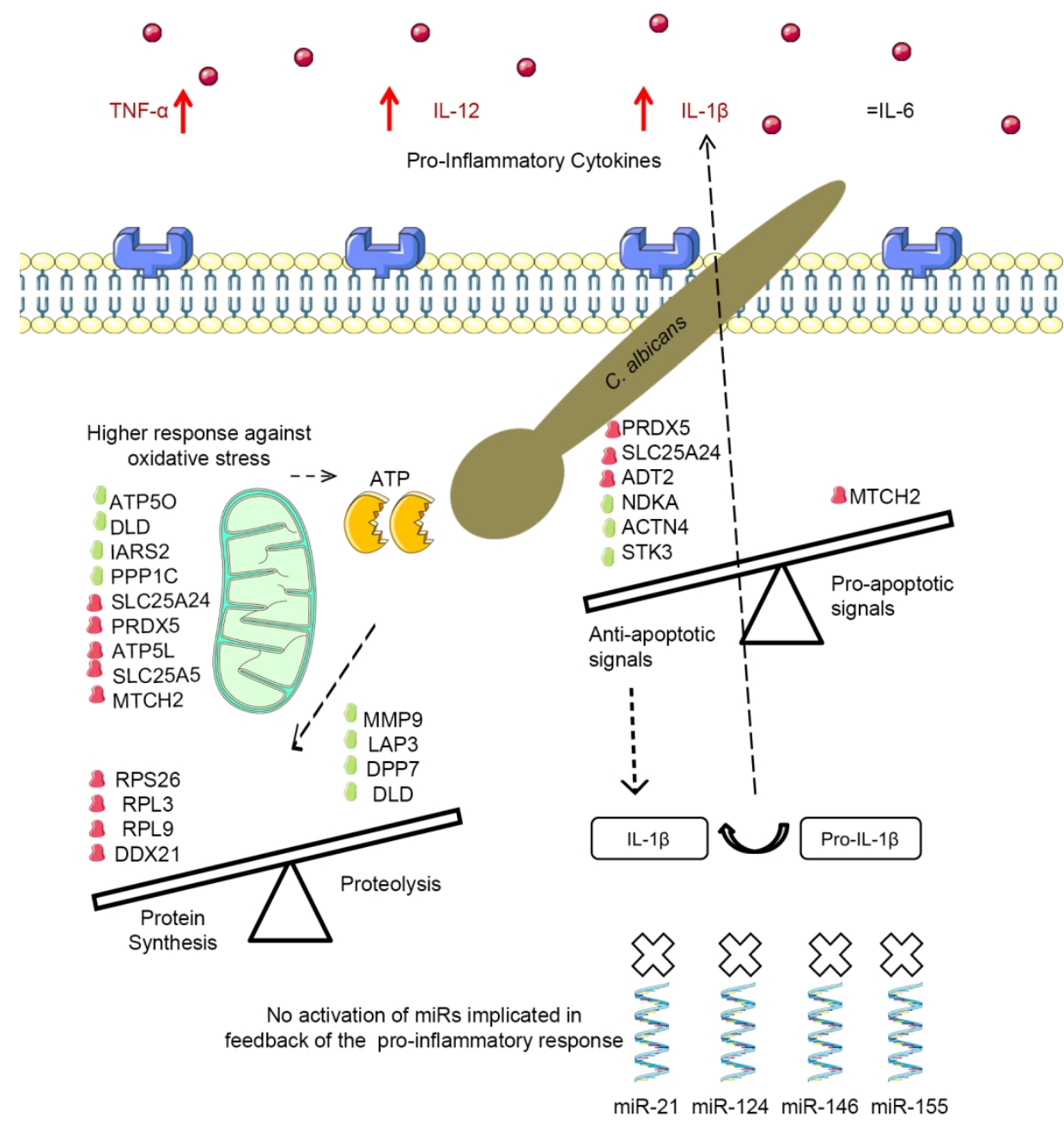

Figure 8. Schematic overview of macrophage possible remodeling after interaction with C. albicans. The differentially abundant proteins, together with the cytokines, are color coded with red for more abundant and green for less abundant after macrophage interaction with $\mathrm{C}$. albicans. The cytokines and the miR that do not present differences after interaction are depicted in grey. The text describes some of the processes suggested to be remodeled after interaction. 


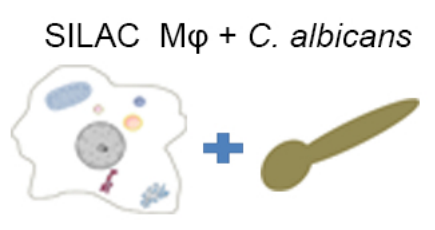

MOI 1 and $3 \mathrm{~h}$ interaction

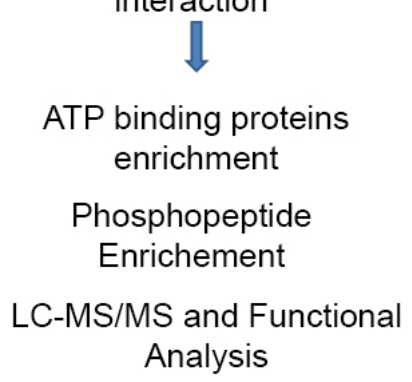

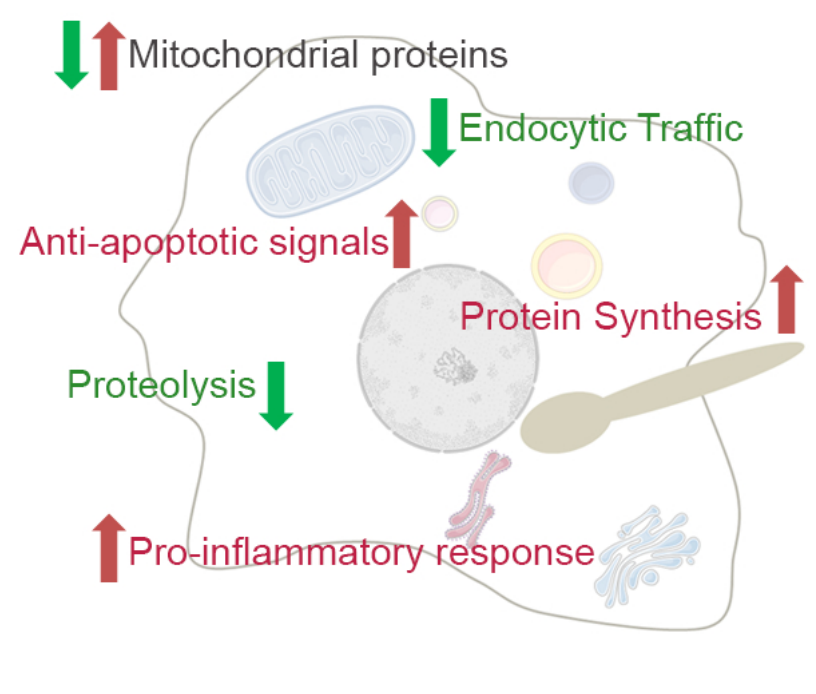

TOC 